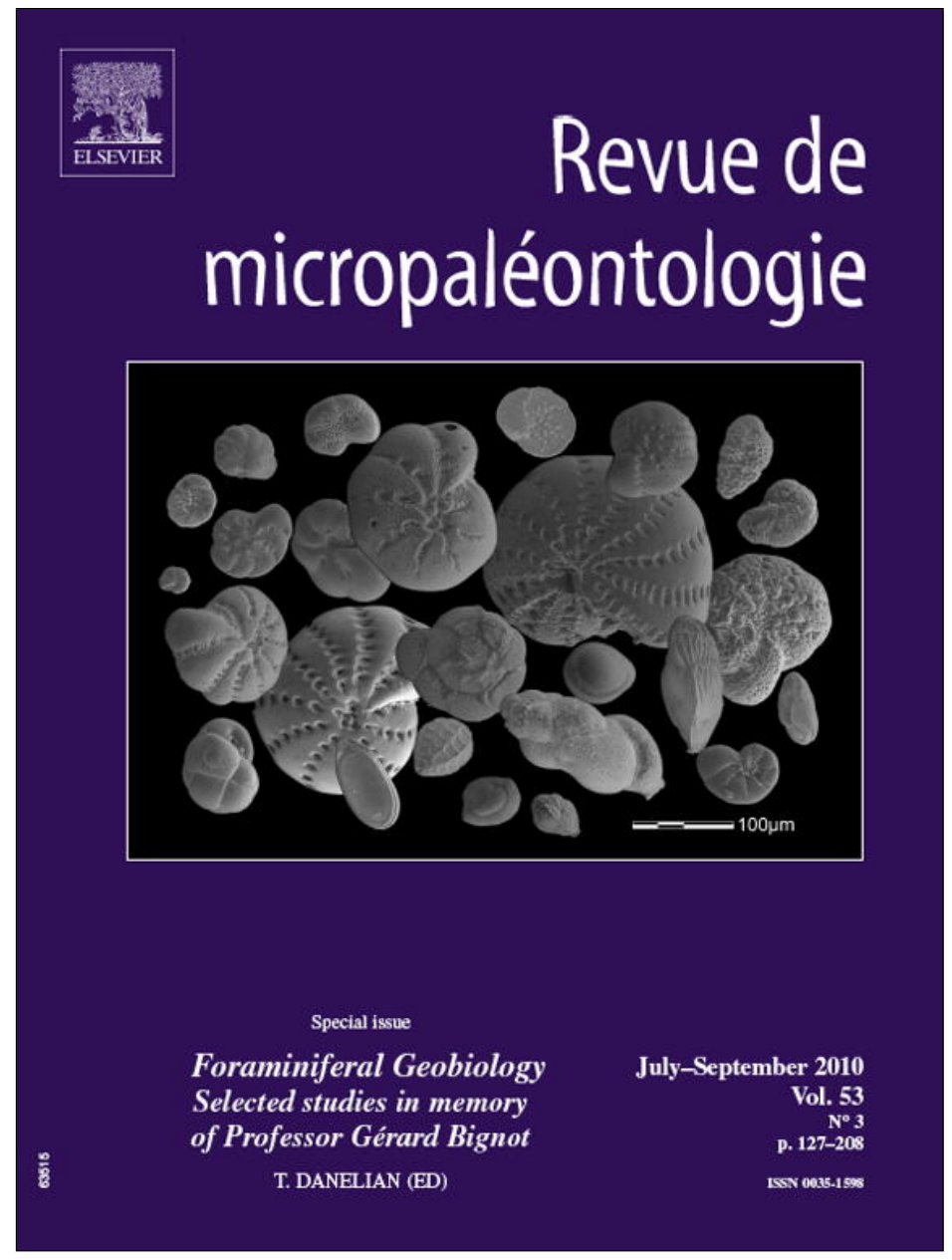

This article appeared in a journal published by Elsevier. The attached copy is furnished to the author for internal non-commercial research and education use, including for instruction at the authors institution and sharing with colleagues.

Other uses, including reproduction and distribution, or selling or licensing copies, or posting to personal, institutional or third party websites are prohibited.

In most cases authors are permitted to post their version of the article (e.g. in Word or Tex form) to their personal website or institutional repository. Authors requiring further information regarding Elsevier's archiving and manuscript policies are encouraged to visit: 
Original article

\title{
Live benthic foraminiferal faunas along a bathymetrical transect (140-4800 m) in the Bay of Biscay (NE Atlantic)
}

\author{
Les foraminifères benthiques vivants le long d'un transect bathymétrique (140-4800 m) dans le \\ Golfe de Gascogne (Atlantique NE)
}

\author{
Meryem Mojtahid $^{\mathrm{a}, \mathrm{b}, \mathrm{c}, *}$, Clémentine Griveaud $^{\mathrm{b}, \mathrm{c}}$, Christophe Fontanier $^{\mathrm{b}, \mathrm{c}}$, Pierre Anschutz $^{\mathrm{d}}$, \\ Fransiscus Josephus Jorissen ${ }^{b, c}$ \\ ${ }^{a}$ National Oceanography Centre, Southampton, Waterfront campus, European way, Southampton SO14 3ZH, United Kingdom \\ ${ }^{\mathrm{b}}$ Laboratoire d'étude des bio-indicateurs actuels et fossiles (BIAF), UFR Sciences, université d'Angers, 2, boulevard Lavoisier, 49045 Angers cedex, France \\ ${ }^{\mathrm{c}}$ Laboratoire d'étude des bio-indicateurs Marins (LEBIM), Ker Chalon, Port Joinville, 85350 Ile d'Yeu, France \\ ${ }^{\mathrm{d}}$ UMR-CNRS 5805 EPOC (Environnements et paléo-environnements océaniques), site de Talence, université de Bordeaux 1, avenue des Facultés, \\ 33405 Talence cedex, France
}

\begin{abstract}
In a 10-stations bathymetrical transect in the Bay of Biscay, we observed important changes in the density, composition and microhabitats of live foraminiferal faunas from the outer continental shelf to the abyssal plain. Four zones are recognised: (1) at the upper continental shelf (140 $\mathrm{m}$ water depth), foraminiferal densities are very high and the superficial sediment is occupied by Bolivina subaenariensis and Valvulineria bradyana. Globobulimina spp., Chilostomella oolina and Nonion fabum dominate the infaunal niches, which are positioned close to the sediment-water interface due to a strong compaction of the vertical succession of redox zones. (2) At the upper continental slope stations (300-1000 m), foraminiferal densities are high and the superficial sediments are dominated by Uvigerina mediterranea/peregrina. Deeper in the sediment, intermediate infaunal niches are occupied by Melonis barleeanus. Due to a deeper oxygen penetration, the deep infaunal taxa Globobulimina spp. and C. oolina live at a considerable depth in the sediment. (3) At the mid and lower slope stations (1000-2000 m) in the superficial sediment Cibicidoides kullenbergi and Hoeglundina elegans progressively replace U. mediterranea. U.peregrina is still a dominant taxon, reflecting its preference for a somewhat intermediate organic flux level. Deep infaunal taxa become increasingly rare. (4) At the lower slope and abyssal plane stations (deeper than $2000 \mathrm{~m}$ ), faunal densities are very low and the fauna is composed exclusively by shallow infaunal species, such as Nuttallides umboniferus and Melonis pompilioides. The foraminiferal data together with the pore water data in the sediment give evidence of the presence of a trophic gradient from very eutrophic settings at the upper continental shelf towards oligotrophic settings at the abyssal area.
\end{abstract}

(C) 2010 Elsevier Masson SAS. All rights reserved.

Keywords: Benthic foraminifera; Bathymetric transect; Trophic levels; Redox conditions; Microhabitat; Bay of Biscay

Résumé

Le long d'un transect bathymétrique de 10 stations dans le Golfe de Gascogne, nous observons des changements importants de la densité, la composition et des microhabitats des faunes de foraminifères benthiques, du plateau continental vers la plaine abyssale. Nous avons pu distinguer quatre zones successives: (1) la partie externe du plateau continental (140 m de profondeur) est caractérisée par des densités très élevées de foraminifères et le sédiment de surface est habité par Bolivina subaenariensis et Valvulineria bradyana. Les niches plus profondes, se trouvant près de l'interface eau-sédiment en raison de la compaction de la succession verticale des zones redox, sont dominées par Globobulimina spp., Chilostomella oolina et Nonion fabum. (2) Dans les environnements du haut de la pente continentale (300-1000 m), les densités sont élevées et le sédiment superficiel est occupé par Uvigerina mediterranea/peregrina. Dans le sédiment, Melonis barleeanus occupe les niches intermédiaires. En raison d'une pénétration d'oxygène maximale, les taxons endopéliques Globobulimina spp. et $C$. oolina vivent profondément dans le sédiment.

\footnotetext{
* Corresponding author.

E-mail address: Meryem.Mojtahid@noc.soton.ac.uk (M. Mojtahid).
} 
(3) Dans les environnements du bas de pente (1000-2000 m), les espèces superficielles Cibicidoides kullenbergi et Hoeglundina elegans remplacent progressivement $U$. mediterranea. U. peregrina reste dominante, ce qui reflète sa préférence pour des flux organiques intermédiaires. Les espèces endobiontes profondes se raréfient. (4) Dans les environnements du bas de pente et de la plaine abyssale (plus de $2000 \mathrm{~m}$ ), les densités sont faibles et la faune est composée exclusivement d'espèces superficielles adaptées aux faibles apports organiques, comme Nuttallides umboniferus et Melonis pompilioides. Les faunes de foraminifères, ainsi que la pénétration d'oxygène dans le sédiment témoignent d'un gradient trophique allant de conditions très eutrophiques dans la partie externe du plateau continental à des conditions oligotrophiques dans les environnements de bas de pente et de la plaine abyssale.

(C) 2010 Elsevier Masson SAS. Tous droits réservés.

Mots clés : Foraminifères benthiques ; Transect bathymétrique ; Conditions redox ; Niveaux trophiques ; Microhabitat ; Golfe de Gascogne

\section{Introduction}

Benthic foraminifera are among the most abundant protists in marine ecosystems. In deep-sea environments, they may represent more than $50 \%$ of the total biomass (Gooday et al., 1992). Due to their short life cycle, high diversity and specific ecological requirements, foraminifera adapt rapidly to the physicochemical conditions of their environment (Murray, 2006). They can respond quickly to the input of organic material (e.g., Gooday, 1988; Silva et al., 1996; Kitazato et al., 2000) by increasing their density (e.g., Kitazato et al., 2000; Fontanier et al., 2003), changing the faunal composition or modifying their microhabitat (Linke and Lutze, 1993; Jorissen et al., 1995; Ohga and Kitazato, 1997). For a long time, certain species have been associated to specific bathymetric ranges (e.g., Phleger, 1951; Parker, 1958; Pujos-Lamy, 1973; Pflum and Frerichs, 1976; Lutze, 1980). Nowadays, it seems accepted that the correlation of these associations with water depth is not very robust (e.g., see review in Jorissen et al., 2007) and that the distributional patterns of foraminiferal species are more related to the organic matter flux to the sea floor and the oxygen content of bottom and pore waters (e.g., Lutze, 1980; Lutze and Coulbourn, 1984; Altenbach and Sarthein, 1989; Loubere, 1991, 1994; Jorissen et al., 1995; Fariduddin and Loubere, 1997; Gooday, 2003; Jorissen et al., 2007). However, other factors (e.g., sedimentary processes, the nature of the substrate, or biological processes, such as competition and predation) also influence the spatial distributional patterns of benthic foraminifera, and may become predominant in specific settings. In open ocean deep-sea environments, the organic matter flux that arrives at the sea floor mostly originates from surface primary production. Because of partial remineralisation in the water column, the amount of organic matter that reaches the sediment and the proportion of labile organic matter decrease with increasing water depth (e.g., Suess, 1980; Berger and Wefer, 1990; Herguera, 1992). In general, the flux of metabolisable organic matter is therefore inversely proportional to water depth.

In a number of previous studies, Fontanier et al. (2002, 2003, 2006) and Langezaal et al. (2006) described the composition, densities and microhabitats of live benthic foraminiferal faunas in the Bay of Biscay along a 5-station bathymetric transect from 140 to $2000 \mathrm{~m}$ depth. Fontanier et al. (2002) showed decreasing faunal densities with increasing water depth and decreasing estimated organic matter flux, and a bathymetrical succession of species, some having a restricted bathymetric range. Certain species adapt to dysoxic/anoxic conditions within the sediments, and show varying microhabitats from one station to another, in function of the precise depth of successive redox boundaries. Fontanier et al. (2003, 2006) described the seasonal and interannual variability of benthic foraminiferal faunas at two stations situated at 550 and $1000 \mathrm{~m}$ water depths. The seasonal variability of the foraminiferal faunas at a $140 \mathrm{~m}$ deep outer shelf station has been described by Langezaal et al. (2006). These authors tried to relate temporal faunal changes to estimations of surface water primary production, which were based on satellite images. This method can perhaps yield acceptable estimates in open ocean settings, where the organic matter flux has an important vertical component. On the contrary, in more marginal environments, lateral sediment transport mechanisms (e.g., by nepheloid layers, or by gravitational processes) tend to be important, and a large part of the organic matter arriving at the sea floor may result from lateral supplies. Schmidt et al. (2009) argue that this is also the case for the Bay of Biscay, especially for sites that are situated in the vicinity of submarine canyons. In such cases, flux equations do no longer give realistic results. Therefore, in this study we use the redox conditions, not only to assess the remineralisation pathways in the sediment, but also as a proxy of the trophic conditions of the benthic ecosystem. At the sediment-water interface, oxygen migrates from the bottom waters into the sediment by molecular diffusion and macrofaunal bio-irrigation. In the superficial sediment, (aerobic) microorganisms preferentially use oxygen for the degradation of organic matter, thereby obtaining the energy necessary for their life functions (growth, reproduction, etc.). Oxygen becomes therefore depleted at a depth of a few millimetres to tens of centimetres below the water/sediment interface, depending on the intensity of organic matter degradation. In eutrophic ecosystems, all oxygen is consumed before all labile organic carbon has been remineralised. In the absence of external disturbances (e.g., sediment burrowing), which can transport oxygen to deeper sediment layers, organic matter degradation then continues by anaerobic pathways, using other electron acceptors, such as nitrates, metal oxides (iron and manganese) and sulfates. In general, the oxygen penetration depth in the sediment is therefore inversely proportional to the amount of organic carbon arriving at the sea floor.

In this paper, we will reconsider the live benthic foraminiferal faunas along the sample transect initially described by Fontanier et al. (2002). We will present new data for five additional sampling stations. These new data will allow us to describe in more detail the influence of the environmental parameters on the density, specific composition and vertical distribution of benthic foraminiferal faunas along the transect. Two of the five new 
stations are positioned at the upper slope (at $320 \mathrm{~m}$ and $800 \mathrm{~m}$ water depth), one at mid-slope $(1600 \mathrm{~m})$, whereas two stations are located at the lower slope $(2400 \mathrm{~m})$ and on the abyssal plain $(4800 \mathrm{~m})$. The main objectives of this paper are:

- to present and discuss variation of the foraminiferal density with increasing water depth and thus, probably with a diminishing organic flux, using a combination of existing data for a five station transect in the Bay of Biscay and new data from five complementary stations $(320 \mathrm{~m}, 800 \mathrm{~m}, 1600 \mathrm{~m}, 2400 \mathrm{~m}$ and $4800 \mathrm{~m}$ water depth);

- to better define the ecological characteristics of the main foraminiferal species, and to explain the microhabitat changes in response to the trophic conditions at the sediment-water interface.

\section{Sampling area, material and methods}

\subsection{Regional setting}

The Bay of Biscay (Fig. 1) is an oceanic embayment, partially closed to the south by the Spanish coast and to the east by the French coast. Water masses in the Bay of Biscay originate from the North Atlantic drift. Surface waters arrive from the north, along the Irish continental shelf, and leave at Cape Finisterre. The surface water patterns are strongly constrained

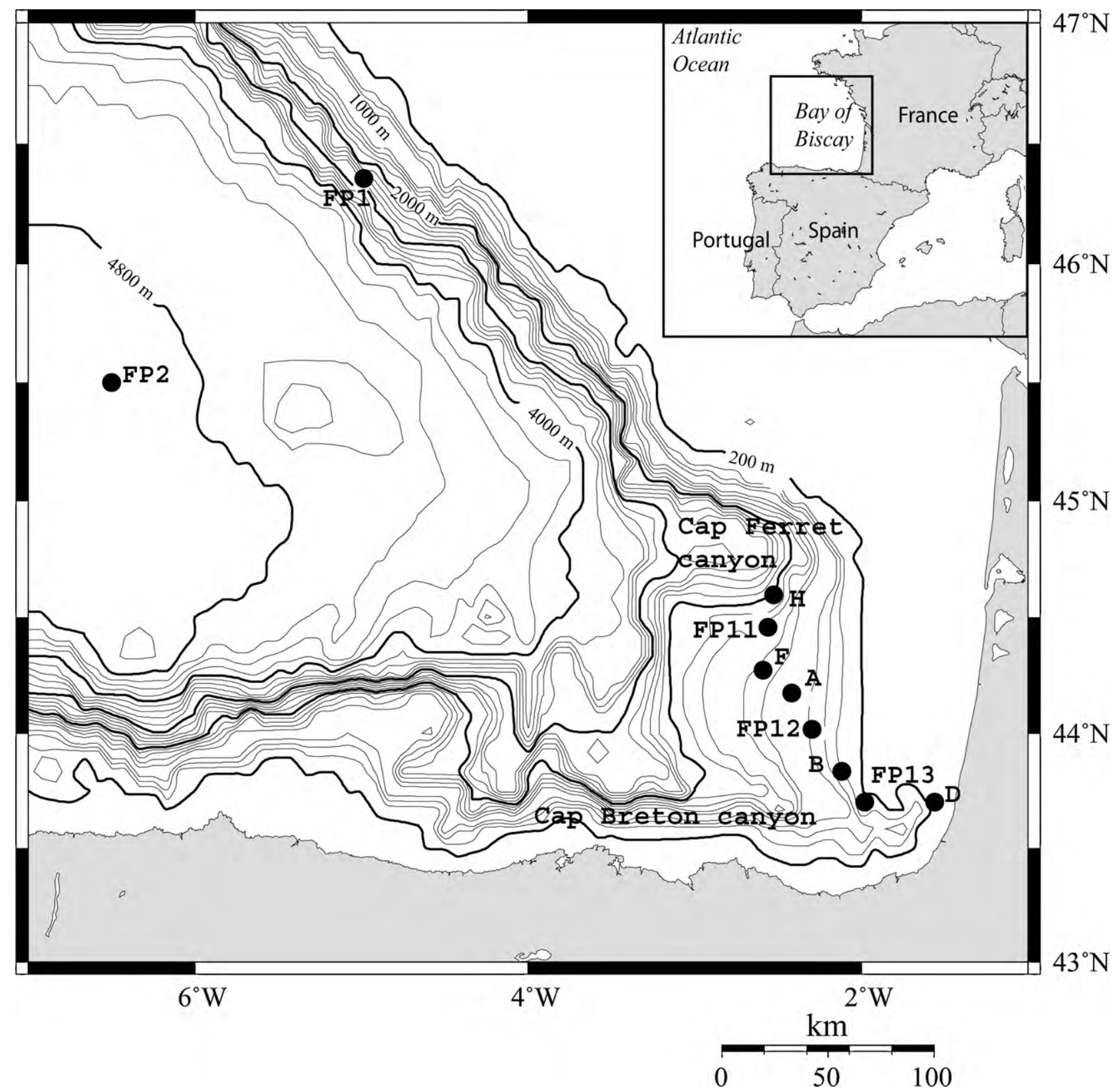

Fig. 1. Study area, bathymetry and geographical position of the 10 stations.

Site d'étude, bathymétrie et localisation des 10 stations. 


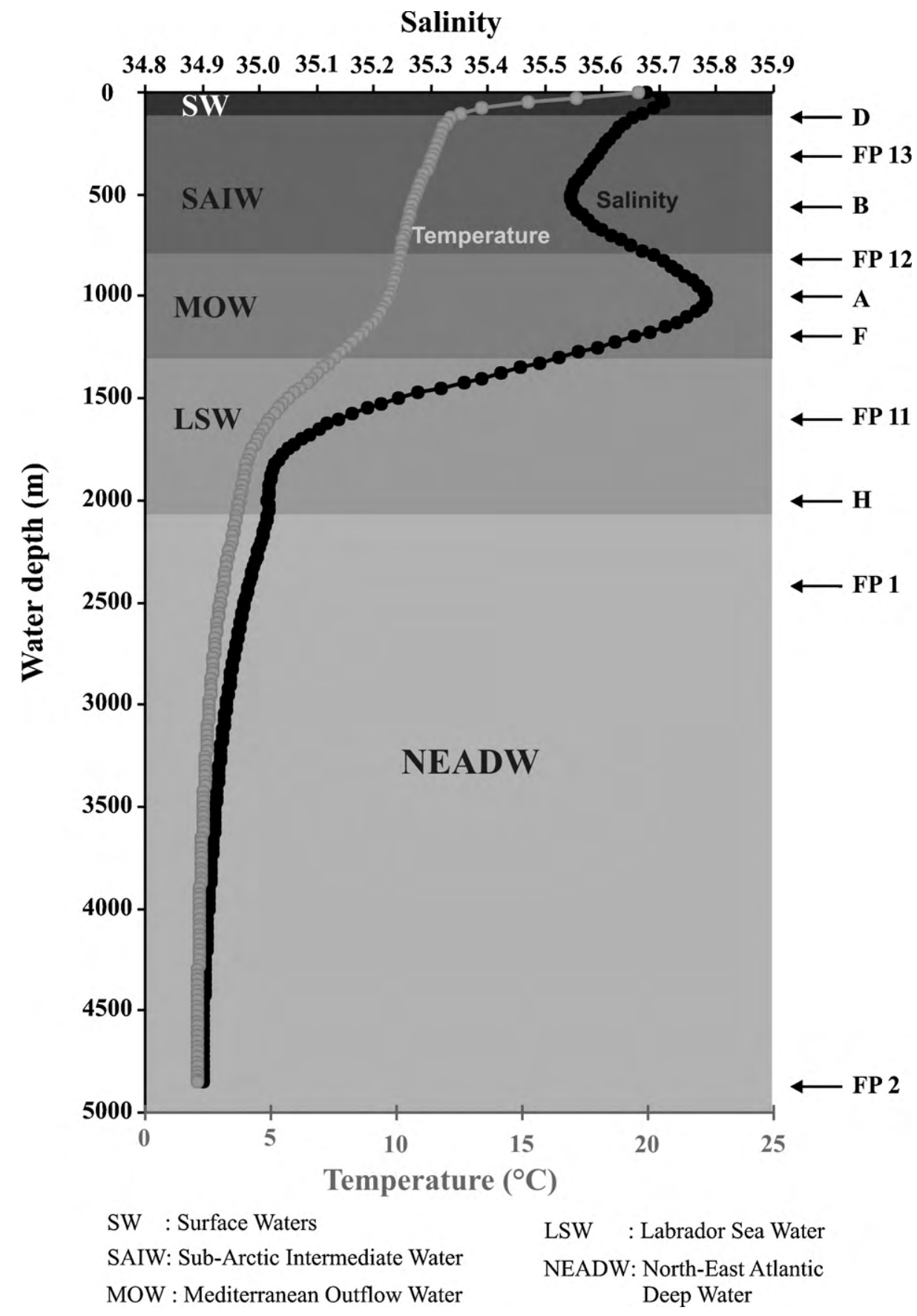

Fig. 2. Salinity and temperature CTD profiles at station FP2 (Van Aken, unpublished data) and the localisation of water masses (After Van Aken, 2000a, 2000b, 2001).

Profiles CTD de salinité et température à la station FP2 (Van Aken, données non-publiées) et localisation des masses d'eau (d'après Van Aken, 2000a, 2000b, 2001).

by seasonal variations of the thermocline and the mixed layer (Tréguer et al., 1979). Below the surface waters $(\sim 150 \mathrm{~m})$, the Sub-Arctic Intermediate Waters (SAIW) are present down to approximately $800 \mathrm{~m}$ depth (Fig. 2) presenting a sub-surface salinity minimum. Between $800 \mathrm{~m}$ and $1300 \mathrm{~m}$, a branch of the Mediterranean Outflow Water (MOW) is present. This branch is slightly less oxygenated $\left(3.8 \mathrm{~mL} \cdot \mathrm{L}^{-1}\right.$, Le Floch, 1968) and presents a higher salinity (35.8) in comparison to the surrounding waters (Fig. 2). Below the Mediterranean waters and until about $2000 \mathrm{~m}$ depth, the Labrador Sea Waters (LSW) are found
(Fig. 2). Deeper, the cold and low salinity North-East Atlantic Deep Waters (NEADW) are present (Fig. 2).

The continental slope bordering the French shelf deepens gradually, and is interrupted by two large canyons (Cap Ferret and Cap Breton Canyons) (Fig. 1). Vertical fluxes represent generally the main sedimentary component in open slope environments (Heussner et al., 1999), but lateral advection may dominate sedimentary processes in and close to the canyons (Heussner et al., 1999; Schmidt et al., 2009). Surface primary production values vary from 145 to $170 \mathrm{gC} / \mathrm{m}^{2} / \mathrm{yr}$ in the Bay 
of Biscay (Laborde et al., 1999). A clear primary production maximum is observed in spring; primary production values are minimal in summer and winter (Tréguer et al., 1979; Laborde et al., 1999).

\subsection{Sediment sampling}

Stations FP1 and FP2 were sampled in August 2003, station FP11 in May 2004, and stations FP12 and FP13 in August 2005 (Table 1). Stations D, B and A were sampled several times between 1997 and 2001, station F was sampled in January 1998 and station $\mathrm{H}$ in October 1998. In the study of Fontanier et al. (2002), only one core per station was investigated. In the present paper, we use also the additional cores analysed in later studies (Fontanier et al., 2003, 2006; Langezaal et al., 2006) at stations D, B and A (Table 1). For these three stations, averaged values are given to describe the faunas of each station. Only cores where the entire ten first centimetres of the sediment were analysed have been considered. Sediments were collected between 140 and $4800 \mathrm{~m}$ water depth using classical Barnett multicorers (Barnett et al., 1984). The corer used during the FORAMPROX1 cruise (stations FP1 and FP2) contained 8 Plexiglas tubes of $6.3 \mathrm{~cm}$ internal diameter (core surface: $\sim 31 \mathrm{~cm}^{2}$ ) whereas the corer used during all other cruises took 8 cores with an internal diameter of $9.5 \mathrm{~cm}$ (core surface: $\sim 71 \mathrm{~cm}^{2}$ ). This sampling method is the most efficient to obtain an undisturbed sediment and water-sediment interface. The ten stations have been selected to compose a SE-NW bathymetrical/trophic transect, ranging from the outer shelf to bathyal open slope environments in the Bay of Biscay.

\subsection{Geochemistry}

At stations FP11, FP12 and FP13, overlying bottom waters were collected immediately after core recovery in order to measure the dissolved oxygen concentrations using the Winkler titration method (Strickland and Parsons, 1972). Profiles of pore water oxygen were obtained onboard with a cathodetype mini-electrode (Revsbeck, 1983; Helder and Bakker, 1985; Revsbeck and Jørgensen, 1986). At stations FP1 and FP2, no measurements were performed of bottom water oxygen concentrations; they were estimated using World Ocean Atlas 2005 data (http://www.nodc.noaa.gov/). For these cores, the depth of the zero oxygen level was estimated on the basis of the manganese and nitrate profiles. At station FP2, we tentatively placed the zero oxygen level at the intersection of the nitrate and $\mathrm{Mn}^{2+}$ profiles. At station $\mathrm{FP} 1, \mathrm{Mn}^{2+}$ profiles were not determined below $9 \mathrm{~cm}$, and our estimated depth of the zero oxygen level is uniquely based on the nitrate profile. See Fontanier et al. (2002, 2003, 2006) and Langezaal et al. (2006) for a description of the other geochemical methods used. Temperature and salinity data listed in Table 1 are the results of a compilation of Conductivity-Temperature-Depth (CTD) measurements performed during three years in the Bay of Biscay (Van Aken, 2000a, 2000b, 2001).

\subsection{Foraminifera}

For faunal analysis, entire cores were sliced horizontally for each station; every half $\mathrm{cm}$ until $4 \mathrm{~cm}$ depth, and every $\mathrm{cm}$ between 4 and $10 \mathrm{~cm}$ (see Fontanier et al., 2002, 2003, 2006; Langezaal et al., 2006 for the sampling strategy used at stations D, B, A, H and F). Sediments were stored in $500 \mathrm{~cm}^{3}$ bottles, which were filled with $95 \%$ ethanol containing 1.0 to $1.2 \mathrm{~g} / \mathrm{L}$ Rose Bengal stain. Rose Bengal staining is commonly used to identify live foraminifera (Walton, 1952). All samples were gently shaken for several minutes in order to obtain a homogeneous mixture. In the laboratory, they were sieved through 63 and $150 \mu \mathrm{m}$ mesh screens, and the sieve residues were stored in $95 \%$ ethanol. Stained foraminifera belonging to the greater than

Table 1

Water depth, number of studied cores, core surface, sampling period, geographical position, bottom water oxygen (BWO), oxygen penetration depth (OPD) in the sediment (see text for full explanation), bottom water salinity and temperature. Stations in bold (FP13, FP12, FP11, FP1 and FP2) are the five newly studied stations. The other stations (D, B, A, F and H) have been studied by Fontanier et al. (2002, 2003, 2006) and Langezaal et al. (2006). At stations FP1 and FP2, BWO values are estimated using World Ocean Atlas 2005 data and OPD values are estimated on the basis of nitrate and Mn ${ }^{2+}$ profiles (see methods section Geochemistry). Profondeur d'eau, nombre des carottes étudiées, surface des carottes, période d'échantillonnage, position géographique, oxygène des eaux de fond (BWO), pénétration d'oxygène dans le sédiment (OPD), salinité et température des eaux de fond. Les stations en gras (FP13, FP12, FP11, FP1 et FP2) sont les cinq nouvelles stations. Les autres stations (D, B, A, F et H) ont été étudiées par Fontanier et al. (2002, 2003, 2006) et Langezaal et al. (2006). Aux stations FP1 et FP2, l'oxygénation des eaux de fond a été estimée à partir des données du «World Ocean Atlas 2005 » et les valeurs de pénétration d'oxygène dans le sédiment ont été estimées sur la base des profiles de nitrates et de manganèse (voir méthodes section Géochimie).

\begin{tabular}{|c|c|c|c|c|c|c|c|c|c|c|}
\hline Station & $\begin{array}{l}\text { Number of } \\
\text { studied cores }\end{array}$ & $\begin{array}{l}\text { Core surface } \\
\left(\mathrm{cm}^{2}\right)\end{array}$ & $\begin{array}{l}\text { Sampling } \\
\text { period }\end{array}$ & $\begin{array}{l}\text { Depth } \\
(\mathrm{m})\end{array}$ & Lat. & Long. & $\begin{array}{l}\text { BWO } \\
\text { umol/L }\end{array}$ & $\begin{array}{l}\text { OPD } \\
(\mathrm{cm})\end{array}$ & $\begin{array}{l}\text { Bottom } \\
\text { Sal. (\%o) }\end{array}$ & $\begin{array}{l}\text { Bottom } \\
\text { Temp. }\left({ }^{\circ} \mathrm{C}\right)\end{array}$ \\
\hline $\mathrm{D}$ & 13 & 70.85 & Oct-97to Apr-01 & 140 & $43^{\circ} 42^{\prime} \mathrm{N}$ & $1^{\circ} 34^{\prime} \mathrm{W}$ & 223 & 0.54 & 35.6 & 12.1 \\
\hline FP13 & 1 & 70.85 & Aug-05 & 320 & $43^{\circ} 42^{\prime} \mathrm{N}$ & $1^{\circ} 59^{\prime} \mathrm{W}$ & 218 & 2 & 35.6 & 11.4 \\
\hline B & 11 & 70.85 & Oct-97 to Apr-01 & 550 & $43^{\circ} 50^{\prime} \mathrm{N}$ & $2^{\circ} 03^{\prime} \mathrm{W}$ & 210 & 1.9 & 35.6 & 10.8 \\
\hline FP12 & 1 & 70.85 & Aug-05 & 800 & $44^{\circ} 00^{\prime} \mathrm{N}$ & $2^{\circ} 15^{\prime} \mathrm{W}$ & 175 & 2.5 & 35.7 & 10.2 \\
\hline A & 12 & 70.85 & Oct-97 to Apr-01 & 1000 & $44^{\circ} 10^{\prime} \mathrm{N}$ & $2^{\circ} 20^{\prime} \mathrm{W}$ & 195 & 2.8 & 35.8 & 9.7 \\
\hline $\mathrm{F}$ & 1 & 70.85 & Jan-98 & 1200 & $44^{\circ} 17^{\prime} \mathrm{N}$ & $2^{\circ} 45^{\prime} \mathrm{W}$ & 210 & 6.3 & 35.6 & 8.4 \\
\hline FP11 & 2 & 70.85 & May-04 & 1600 & $44^{\circ} 27^{\prime} \mathrm{N}$ & $2^{\circ} 39^{\prime} \mathrm{W}$ & 250 & 4.5 & 35.3 & 5.8 \\
\hline $\mathrm{H}$ & 1 & 70.85 & Oct-98 & 2000 & $44^{\circ} 32^{\prime} \mathrm{N}$ & $2^{\circ} 37^{\prime} \mathrm{W}$ & 261 & 6.23 & 35.1 & 4.1 \\
\hline FP1 & 6 & 31.16 & Aug-03 & 2400 & $46^{\circ} 20^{\prime} \mathrm{N}$ & $5^{\circ} 00^{\prime} \mathrm{W}$ & 268 & 9 & 35 & 3.3 \\
\hline FP2 & 6 & 31.16 & Aug-03 & 4800 & $45^{\circ} 30^{\prime} \mathrm{N}$ & $6^{\circ} 30^{\prime} \mathrm{W}$ & 268 & 8 & 34.9 & 2.5 \\
\hline
\end{tabular}


$150 \mu \mathrm{m}$ fraction were sorted from wet samples, and stored in Chapman slides. For some of the stations, the 63-150 $\mu \mathrm{m}$ fraction was studied for the uppermost levels. The data for this small size fraction are not considered in this paper. A potential problem of the Rose Bengal staining technique is the fact that Rose Bengal may stain the protoplasm of dead foraminifera, which may be relatively well preserved for a considerable period of time under the anoxic conditions that generally prevail deeper in the sediment (Bernhard, 1988; Corliss and Emerson, 1990; Bernhard et al., 2006). Consequently, a strict application of the staining criteria is most times easy in superficial samples, but may become more critical in the deeper levels. In all cases, we applied our staining criteria (all chambers except the last one stained brightly pink) very strictly, and compared doubtful individuals with perfectly stained individuals of the same species found in superficial sediment layers. Non-transparent agglutinated and miliolid taxa were broken on many occasions for inspection of the interior of the test. We tried to identify most of live foraminifera at species level.

All data presented by Fontanier et al. $(2002,2003,2006)$ and Langezaal et al. (2006) are based on the study of single cores with a surface area of $\sim 71 \mathrm{~cm}^{2}$. When data on more than one core are available (either replicate cores or cores at different sampling periods), average values (with standard errors) are used. New data are based on a single $\sim 71 \mathrm{~cm}^{2}$ core for stations FP12 and FP13 and on two $\sim 71 \mathrm{~cm}^{2}$ cores for station FP11. Finally, for stations FP1 and FP2, 6 cores with a surface area of $\sim 31 \mathrm{~cm}^{2}$ were studied. In order to be able to compare the cores, all densities have been standardized for a sediment surface of $50 \mathrm{~cm}^{2}$. For all vertical profiles, densities are standardized for $50 \mathrm{~cm}^{3}$ sediment volume (see appendices for raw data).

In order to describe the vertical distribution of the total faunas or individual taxa, we use the Average Living Depth $\left(\mathrm{ALD}_{\mathrm{x}}\right.$, Jorissen et al., 1995), which allows a rapid description of the microhabitat patterns. The $\mathrm{ALD}_{\mathrm{x}}$ is calculated with the following formula:

$\mathrm{ALD}_{\mathrm{x}}=\sum_{i=0, x}\left(n_{i} \times D_{i}\right) / N$

- $\mathrm{x}=$ lower boundary of deepest sample

- $\mathrm{n}_{\mathrm{i}}=$ number of individuals in interval $\mathrm{i}$

- $\mathrm{D}_{\mathrm{i}}=$ midpoint of sample interval $\mathrm{i}$

- $\mathrm{N}=$ total number of individuals for all levels.

For all stations, $\mathrm{ALD}_{10}$ was calculated for the whole fauna as well as for individual taxa, on the basis of the numbers of stained individuals found in the successive sediment slices. Isolated individuals separated from the main population by more than $1 \mathrm{~cm}$ of "sterile" sediment (without live individuals of the studied taxa) were not considered in the calculations of the ALD 10 . We suppose that such isolated individuals have been transported downward (outside their normal microhabitat) by bioturbation, or correspond to dead organisms that have been counted erroneously. In the data sheets, the latter individuals are indicated in italics. After the first classification with four main microhabitats proposed by Corliss and Chen (1988), it was argued that only species living on elevated substrates can be considered as "epifaunal" (Buzas et al., 1993). Therefore, in the soft bottom communities described in this study, we recognize only three different groups: shallow infaunal, intermediate infaunal and deep infaunal species.

\section{Results}

Fontanier et al. (2002, 2003, 2006) and Langezaal et al. (2006) have presented results of foraminiferal densities, species composition and microhabitats for 5 stations (D, B, A, F and $\mathrm{H}$ ) located on the continental slope of the Bay of Biscay, at water depths ranging from 140 to $2000 \mathrm{~m}$. In this paper, we investigated live faunas from five additional stations: FP13 $(320 \mathrm{~m})$, FP12 (800 m), FP11 (1600 m), FP1 (2400 m) and FP2 (4800 m).

\subsection{Benthic geochemical processes}

For the 10 stations of the bathymetric transect, data for bottom water oxygen concentration, inferred oxygen penetration depth in the sediment, bottom water salinity and temperature are summarized in Table 1. The pore water profiles of the 5 new stations are presented in Fig. 3.

Bottom water oxygen concentration varies ranging from $175 \mu \mathrm{mol} / \mathrm{L}$ at station FP12 (bathed by Mediterranean Outflow Waters; Fig. 2) to $268 \mu \mathrm{mol} / \mathrm{L}$ at stations FP1 and FP2 (bathed by North-East Atlantic Deep Waters; Fig. 2). The depth of oxygen penetration into the sediment is minimal $(\sim 0.5 \mathrm{~cm})$ at the outer shelf station D $(140 \mathrm{~m})$, and progressively increases with water depth, until maximum values of about $9 \mathrm{~cm}$ are reached at 2400 and $4800 \mathrm{~m}$ depth, respectively (Fig. 4[A]).

\subsection{Live foraminiferal densities and composition}

Fig. 4(B, C) shows densities of live benthic foraminifera plotted against the water depth and the oxygen penetration depth in the sediment. For stations that were sampled several times (D, $\mathrm{B}$ and $\mathrm{A}$ ), during different sampling campaigns, the arithmetic average of foraminiferal densities, and standard deviations are represented on the graph. Decreasing densities of live faunas are observed with increasing water depth and increasing oxygen penetration depth. Densities range from $1430 \mathrm{ind} . / 50 \mathrm{~cm}^{2}$ at the shallowest station D $(140 \mathrm{~m})$ to $28 \mathrm{ind} . / 50 \mathrm{~cm}^{2}$ at the deepest station FP2 (Table 2).

Live faunas from the previously studied stations are described in detail in Fontanier et al. (2002, 2003, 2006) and Langezaal et al. (2006). Here, we will only describe the five newly added stations (Fig. 5):

- at station FP13 (320 m), a total of 485 live individuals are found in the studied core $\left(\sim 71 \mathrm{~cm}^{2}\right)$, corresponding to a density of 342 ind. $/ 50 \mathrm{~cm}^{2}$ (Table 2; Appendix A). The maximal density, of 141 ind.$/ 50 \mathrm{~cm}^{3}$, is found in the second half centimetre of the sediment (Fig. 5). Faunal density decreases progressively until $10 \mathrm{~cm}$ depth where only $\sim 1$ ind. $/ 50 \mathrm{~cm}^{3}$ is found. Major taxa ( $\geq 5.0 \%$ of the total fauna) are Bigenerina nodosaria (19.8\%), Globobulimina spp. (17.5\%), Melonis barleeanus (13.6\%) and Chilostomella oolina $(7.6 \%)$; 
M. Mojtahid et al. / Revue de micropaléontologie 53 (2010) 139-162

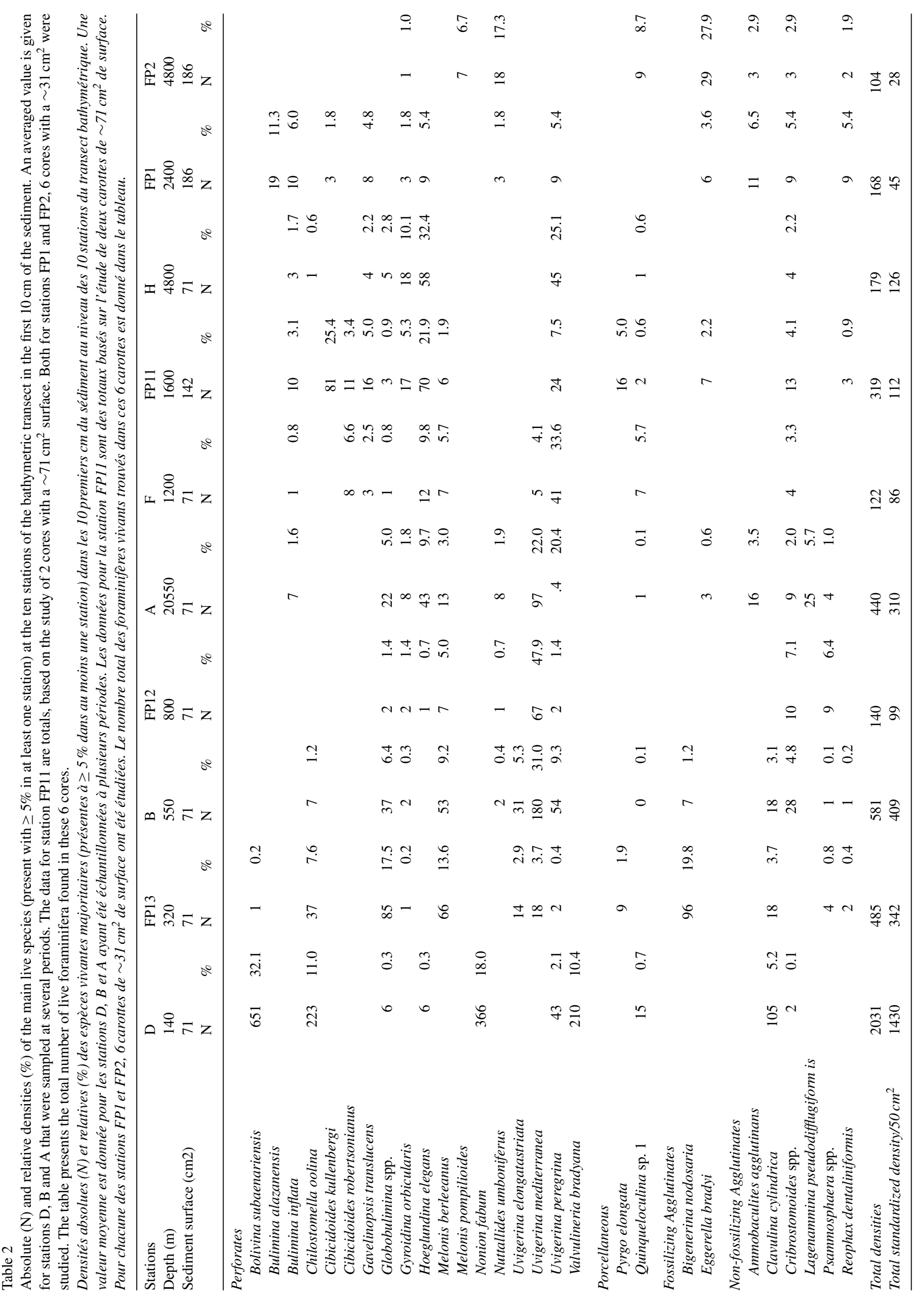


FP 13

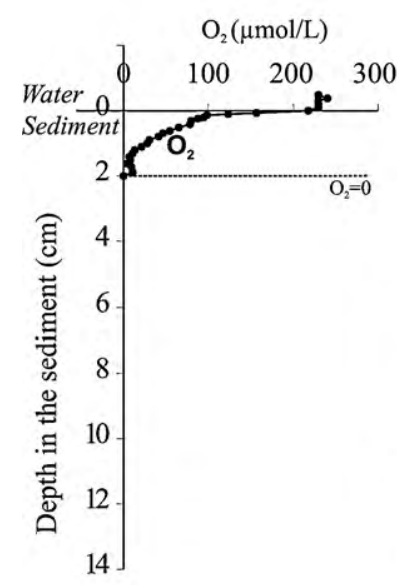

FP 12

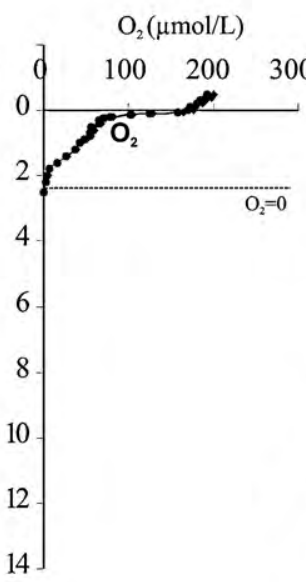

FP 11

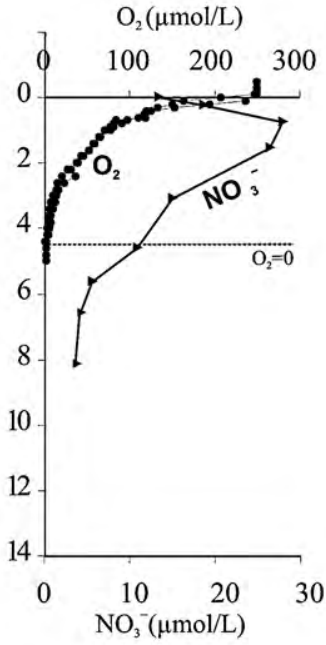

FP 1

FP 2
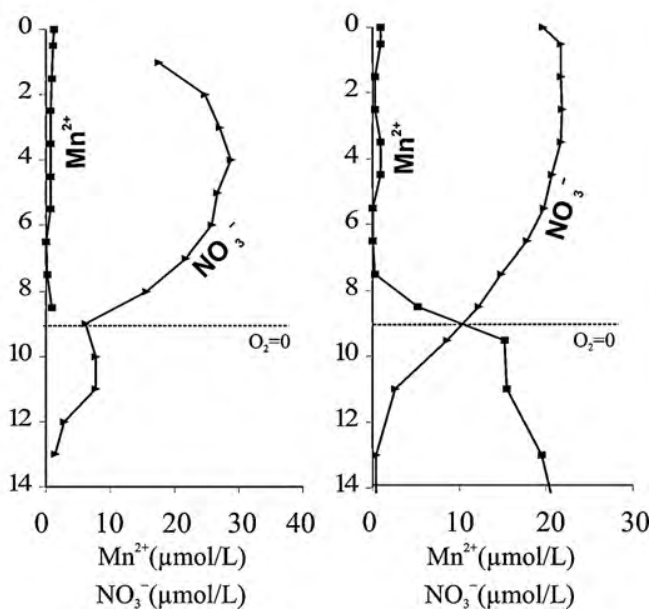

Fig. 3. Pore water data at the five new stations FP13 (320 m), FP12 (800 m), FP11 (1600 m), FP1 (2400 m) and FP2 (4800 m). At stations FP1 and FP2, the oxygen penetration limit is estimated on the basis of nitrate and $\mathrm{Mn}^{2+}$ profiles (see methods section Geochemistry).

Données géochimiques du sédiment au niveau des cinq nouvelles stations FP13 (320 m), FP12 (800 m), FP11 (1600 m), FP1 (2400 m) et FP2 (4800 m). Aux stations FP1 et FP2, l'estimation de la limite de pénétration d'oxygène dans le sédiment est basée sur les profiles de nitrates et de manganèse (voir méthodes, section Géochimie).

- at station FP12 $(\mathbf{8 0 0} \mathbf{~ m}), 140$ live benthic foraminifera were found in the studied core $\left(\sim 71 \mathrm{~cm}^{2}\right)$, corresponding to 99 ind. $/ 50 \mathrm{~cm}^{2}$ (Table 2; Appendix B). A maximum density is found in the first half centimetre of the sediment $\left(\sim 112\right.$ ind. $/ 50 \mathrm{~cm}^{3}$ ) (Fig. 5). The density decreases rapidly towards deeper sediment levels. Below $3 \mathrm{~cm}$, live fauna is nearly absent. Major taxa ( $\geq 5.0 \%$ of the total fauna) are Uvigerina mediterranea (47.9\%), Cribrostomoides spp. (7.1\%), Psammosphaera spp. (6.4\%) and Melonis barleeanus $(5.0 \%)$;

- at station FP11 (1600 m), 2 cores (surface area $\sim 71 \mathrm{~cm}^{2}$ ) were studied, which contained a total of 319 live foraminifera, corresponding to 112 ind. $/ 50 \mathrm{~cm}^{2}$ (Table 2; Appendix C). The maximal density $\left(99 \mathrm{ind} . / 50 \mathrm{~cm}^{3}\right.$ ) is found in the first half centimetre (Fig. 5). The density decreases very rapidly down core, attaining less than 10 ind.$/ 50 \mathrm{~cm}^{3}$ in the $1-1.5 \mathrm{~cm}$ level. Faunal density remains below this value until the bottom of the core. The live foraminiferal assemblage is dominated by $\mathrm{Cibi-}$ cidoides kullenbergi (25.4\%), Hoeglundina elegans (21.9\%), Uvigerina peregrina (7.5\%), Gyroidina orbicularis (5.3\%), Gavelinopsis translucens (5.0\%) and Pyrgo elongata (5.0\%);

- at station FP1 (2400 m), a total density of 168 individuals was obtained for the 6 studied cores (each with a $\sim 31 \mathrm{~cm}^{2}$ surface area), corresponding to 45 ind. $/ 50 \mathrm{~cm}^{2}$ (Table 2; Appendix D). Foraminifera are strongly concentrated in the first half $\mathrm{cm}$ of the sediment $\left(65\right.$ ind.$\left./ 50 \mathrm{~cm}^{3}\right)$ (Fig. 5). About 10 ind.$/ 50 \mathrm{~cm}^{3}$ are found in the $0.5-1 \mathrm{~cm}$ and $1-1.5 \mathrm{~cm}$ intervals, whereas only some specimens are found between 1.5 and $2.5 \mathrm{~cm}$ depth. No live specimens have been found deeper in the core. This station is characterized by the presence of 45 different taxa, no species being strongly predominant. On Fig. 5, only species that occur with more than $5.0 \%$ are represented. Major species are Bulimina alazanensis (11.3\%), Bulimina inflata $(6.0 \%)$, Uvigerina peregrina (5.4\%), Hoeglundina elegans (5.4\%), and three agglutinated species: Ammobaculites agglutinans (6.5\%); Cribrostomoides spp. (5.4\%) and Reophax dentaliniformis (5.4\%);

- station FP2 $\mathbf{( 4 8 0 0} \mathbf{m})$ is characterized by the lowest foraminiferal densities in the sampled transect: a total of 104 individuals was found in the 6 studied cores (each with a $\sim 31 \mathrm{~cm}^{2}$ surface area), corresponding to 28 ind. $/ 50 \mathrm{~cm}^{2}$ (Table 2; Appendix E). A maximum of 32 ind. $/ 50 \mathrm{~cm}^{3}$ is present in the first half centimetre of the sediment (Fig. 5). Faunas are dominated by Eggerella bradyi (27.9\%), Nuttallides umboniferus (17.3\%), Quinqueloculina sp. 1 (8.7\%) and Melonis pompilioides $(6.7 \%)$.

\subsection{Microhabitats of live foraminifera}

For the newly analysed stations, the vertical distribution of the total assemblage is shown in Fig. 5. ALD 10 values for total faunas and for the dominant species are presented in Fig. 6 and Table 3:

- at station FP13 $(320 \mathrm{~m})$, the $\mathrm{ALD}_{10}$ of the entire fauna is $2.3 \mathrm{~cm}$. Bigenerina nodosaria is a shallow infaunal taxon $\left(\mathrm{ALD}_{10}=0.7 \mathrm{~cm}\right)$, Melonis barleeanus occupies intermediate infaunal niches $\left(\mathrm{ALD}_{10}=2.0 \mathrm{~cm}\right)$ and Chilostomella oolina and Globobulimina spp. are deep infaunal species $\left(\mathrm{ALD}_{10}=4.8\right.$ and $4.6 \mathrm{~cm}$, respectively);

- at station FP12 $(800 \mathrm{~m})$, the $\mathrm{ALD}_{10}$ of the entire fauna is $0.8 \mathrm{~cm}$. Uvigerina mediterranea, Cribrostomoides spp. and Psammosphaera spp. are shallow infau- 

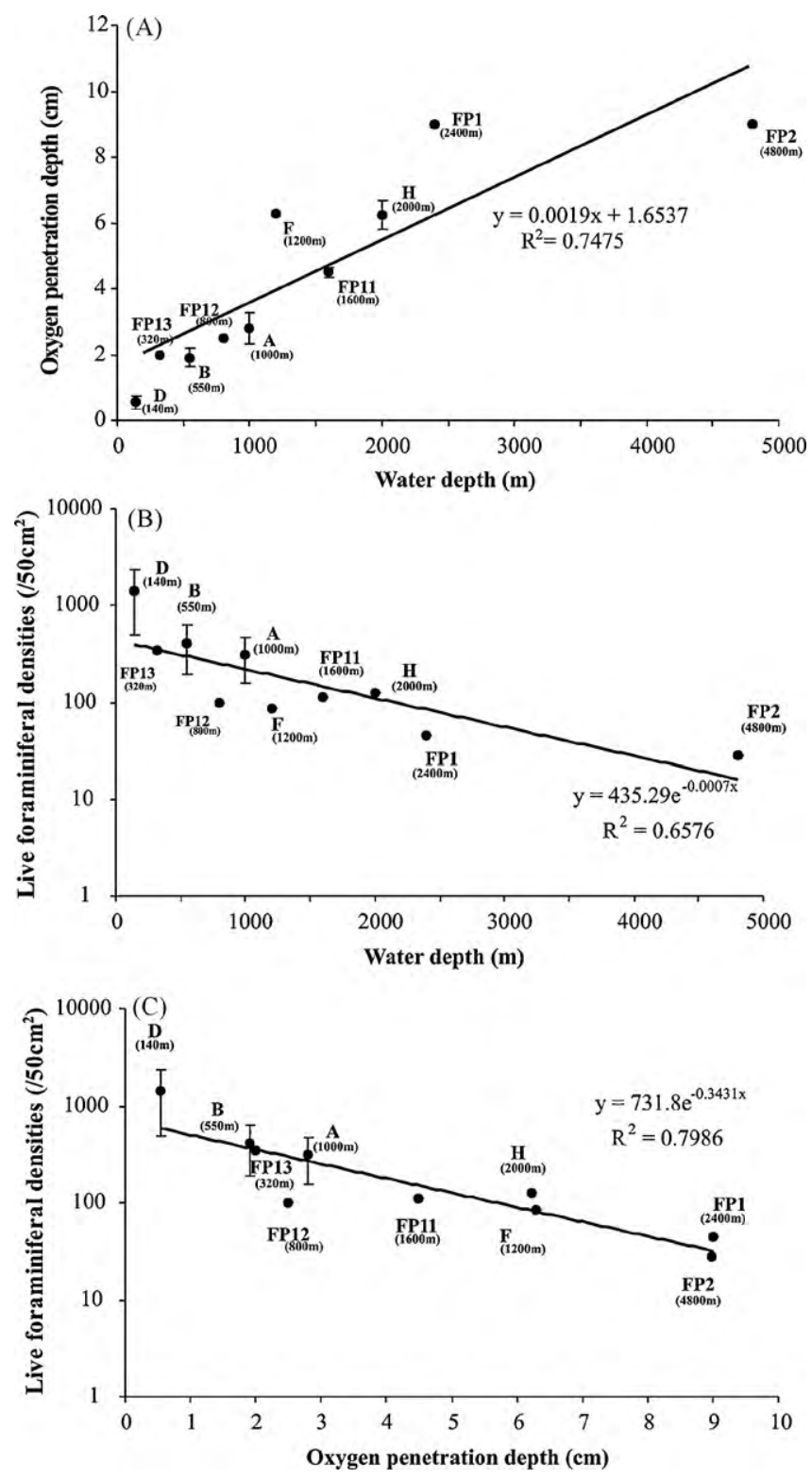

Fig. 4. A. Relationship between the oxygen penetration depth and the water depth along the 10-stations bathymetric transect. At stations FP1 and FP2, oxygen penetration depth into sediment was estimated following nitrate and $\mathrm{Mn}^{2+}$ sediment concentrations. See methods, section Geochemistry for full explanation. The error bars represent the variability in oxygen profiles at the stations sampled and/or measured several times. B. Live foraminiferal densities (standardized for a $50 \mathrm{~cm}^{2}$ sediment surface, for a $10-\mathrm{cm}$-long core) as a function of water depth; C. Live foraminiferal densities (standardized for a $50 \mathrm{~cm}^{2}$ sediment surface, for a 10-cm-long core) as a function of oxygen penetration depth into the sediment. The error bars in Fig. 4 (B, C) represent the variability in foraminiferal densities at the stations sampled and/or measured several times. A. Profondeur de pénétration d'oxygène dans le sédiment en fonction de la profondeur d'eau dans les 10 stations du transect bathymétrique. Aux stations FP1 et FP2, la pénétration d'oxygène dans le sédiment est estimée à partir des mesures de nitrates et de manganèse (voir méthodes, section Géochimie). Les bars d'erreurs représentent la variabilité des mesures d'oxygène aux stations échantillonnées et/ou mesurées plusieurs fois; B. Densités des foraminifères vivants (standardisées pour une surface de $50 \mathrm{~cm}^{2}$, pour une carotte de $10 \mathrm{~cm}$ de long) en fonction de la profondeur d'eau; C. Densités des foraminifères vivants (standardisées pour une surface de $50 \mathrm{~cm}^{2}$, pour une carotte de $10 \mathrm{~cm}$ de long) en fonction de la pénétration d'oxygène dans le sédiment. Les barres d'erreur sur la Fig. $4(B, C)$ représentent la variabilité des densités des foraminifères au niveau des stations échantillonnées et/ou mesurées plusieurs fois. nal species $\left(\mathrm{ALD}_{10}=0.7,0.7\right.$, and $0.3 \mathrm{~cm}$, respectively) while $M$. barleeanus inhabits intermediate microhabitats $\left(\mathrm{ALD}_{10}=1.1 \mathrm{~cm}\right)$;

- at station FP11 $(1600 \mathrm{~m})$, the $\mathrm{ALD}_{10}$ of the entire fauna is $1.3 \mathrm{~cm}$. Hoeglundina elegans and Gavelinopsis translucens have the most superficial microhabitat $\left(\mathrm{ALD}_{10}=0.3 \mathrm{~cm}\right)$, followed by Cibicidoides kullenbergi $\left(\mathrm{ALD}_{10}=0.5 \mathrm{~cm}\right)$, Pyrgo elongata and Uvigerina peregrina $\left(\mathrm{ALD}_{10}=0.6 \mathrm{~cm}\right)$. Gyroidina orbicularis $\left(\mathrm{ALD}_{10}=1.5 \mathrm{~cm}\right)$ occupies a somewhat deeper microhabitat;

- at station FP1 $(2400 \mathrm{~m})$, the $\mathrm{ALD}_{10}$ of the entire fauna is only $0.5 \mathrm{~cm} . H$. elegans and Bulimina inflata are only present in the first half centimetre $\left(\mathrm{ALD}_{10}=0.3 \mathrm{~cm}\right)$. Ammobaculites agglutinans, U. peregrina, Bulimina alazanensis and Cribrostomoides spp. are present at the surface and slightly deeper in the sediment $\left(\mathrm{ALD}_{10}=0.3,0.4,0.5\right.$ and $0.7 \mathrm{~cm}$, respectively), whereas Reophax dentaliniformis reaches a maximal density at $1-1.5 \mathrm{~cm}$ sediment level $\left(\mathrm{ALD}_{10}=0.9 \mathrm{~cm}\right)$;

- at station FP2 (4800 m), all dominant species are restricted to the superficial sediment layer. Melonis pompilioides, Nuttallides umboniferus, Eggerella bradyi and Quinqueloculina seminula have an $\mathrm{ALD}_{10}$ between 0.3 and $0.6 \mathrm{~cm}$. The $\mathrm{ALD}_{10}$ of the total fauna is $0.5 \mathrm{~cm}$.

Fig. 6 (upper panel) shows the spatial evolution of the $\mathrm{ALD}_{10}$ of the total faunas along the bathymetrical transect. The ALD 10 is maximum $(>1.5 \mathrm{~cm})$ at the outer shelf and upper slope stations. It varies between 0.8 and $1.3 \mathrm{~cm}$ for the stations between 550 and $2000 \mathrm{~m}$ depth, and becomes minimal (about $0.5 \mathrm{~cm}$ ) at the two deepest stations (2400 and 4800 depth). This general decrease in $\mathrm{ALD}_{10}$ values with increasing water depths seems to be largely caused by a strong decrease in the density of intermediate and deep infaunal taxa (C. oolina, Globobulimina spp., G. orbicularis, M. barleeanus, N. fabum and U. elongatastriata) as shown in the upper panel of Fig. 6.

The lower panel of Fig. 6 shows the ALD 10 of three species that are representative for the three main microhabitat patterns that we find in the Bay of Biscay: Uvigerina peregrina occupies a superficial infaunal microhabitat, Melonis barleeanus is always found in an intermediate infaunal niche and Globobulimina spp. systematically lives in a deep infaunal microhabitat. In Fig. 5, we can notice that the superficial taxon $U$. peregrina has a tendency towards a shallower microhabitat at deeper sites, whereas the intermediate and deep infaunal species M. barleeanus and Globolulimina spp. deepen their microhabitat towards deeper sites. The trend of the deeper infaunal species corresponds to a similar tendency observed for oxygen penetration into the sediment, which also increases towards deeper sites.

\section{Discussion}

\subsection{Pore water oxygenation}

Along the bathymetric/trophic transect, the oxygen penetration depth into the sediment shows a gradual increase from shallow to deeper sites. Although the oxygen penetration depth is controlled by several parameters (supply of labile 


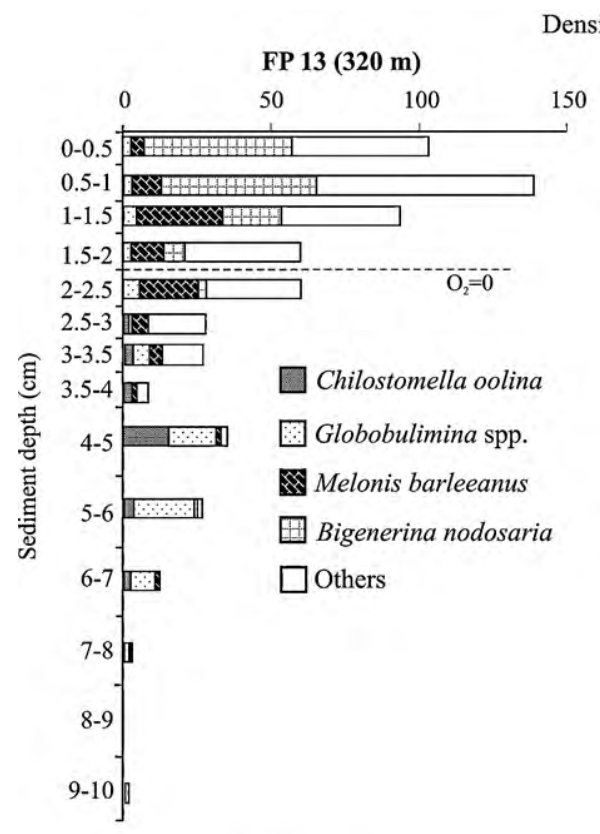

ensity of live foraminifera per $50 \mathrm{~cm}^{3}$ sediment volume
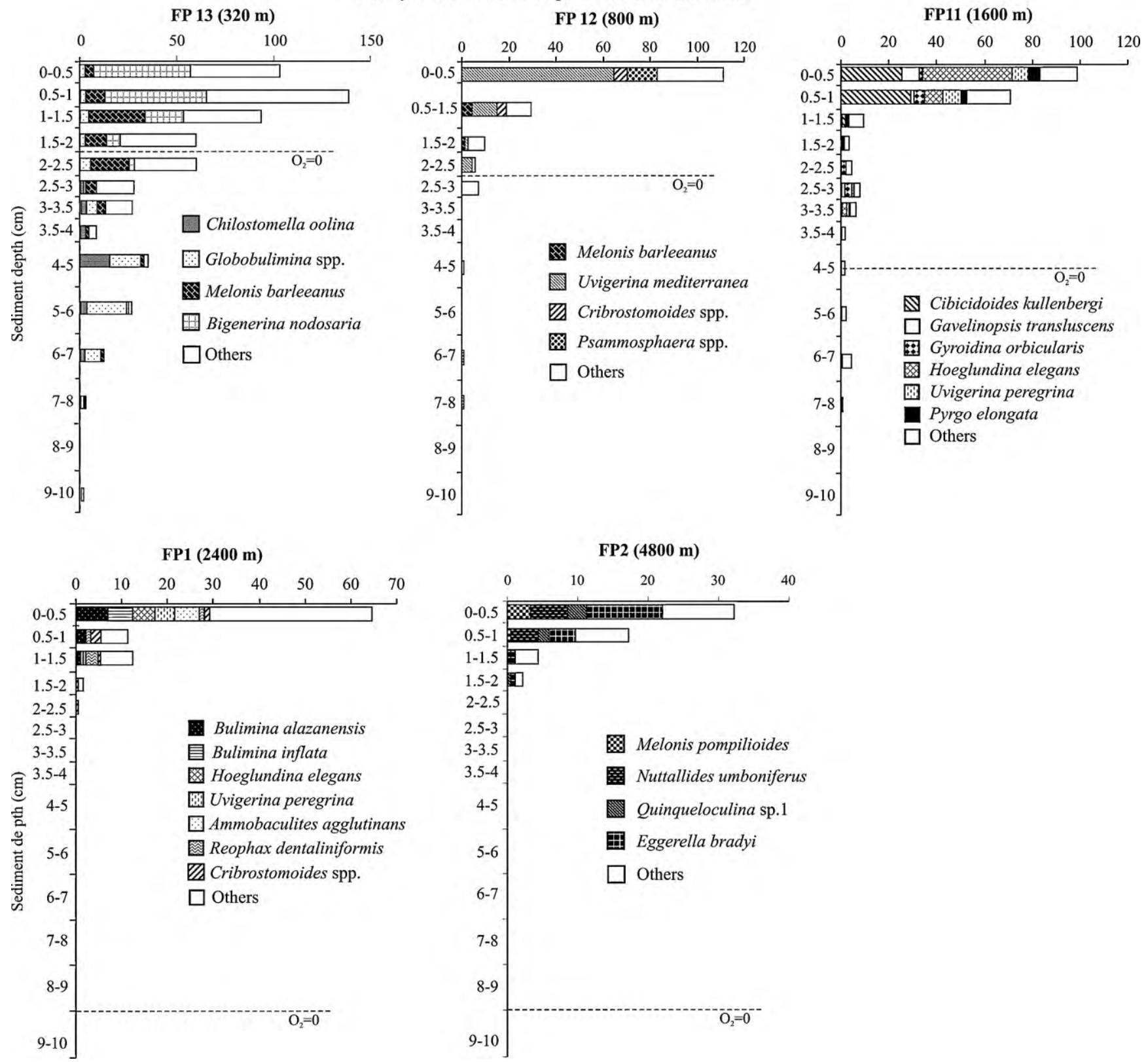

Fig. 5. Foraminiferal distribution (number of individuals found in each level, standardized for a $50 \mathrm{~cm}^{3}$ sediment volume) of the main species (present with a percentage higher than 5\%) at stations FP13 $(320 \mathrm{~m})$, FP12 $(800 \mathrm{~m})$, FP11 $(1600 \mathrm{~m})$, FP1 $(2400 \mathrm{~m})$ and FP2 (4800 m). The dashed lines represent the maximum oxygen penetration depths.

Distribution (nombre d'individus trouvés à chaque niveau de la carotte, standardisé pour $50 \mathrm{~cm}^{3}$ de sédiment) des espèces majoritaires (présentes à $\geq 5 \%$ dans au moins une station) au niveau des stations FP13 (320 m), FP12 (800 m), FP11 (1600 m), FP1 (2400 m) et FP2 (4800 m). Les lignes en pointillés représentent les limites maximum de pénétration d'oxygène dans le sédiment.

organic carbon, sediment porosity and bioturbation), it is mainly determined by the balance between downward diffusion and oxygen consumption in the sediment, due to aerobic organic carbon remineralisation and the oxidation of reduced products of anaerobic mineralization (e.g., Hyacinthe et al., 2001). It appears therefore that the very clear tendency of deeper oxygen penetration with increasing water depth reflects a strong decrease of metabolisable organic particles in function of water depth.

\subsection{Densities of live foraminifera}

Although we have no direct way to quantify the trophic level at any of our sampling stations, foraminiferal assemblages and pore water characteristics should vary in function of the amount of metabolisable organic carbon. As we saw in the previous paragraph, the oxygen penetration in the sediment should increase with a decreasing labile organic carbon flux to the sea floor. Simultaneously, the density of the foraminiferal 


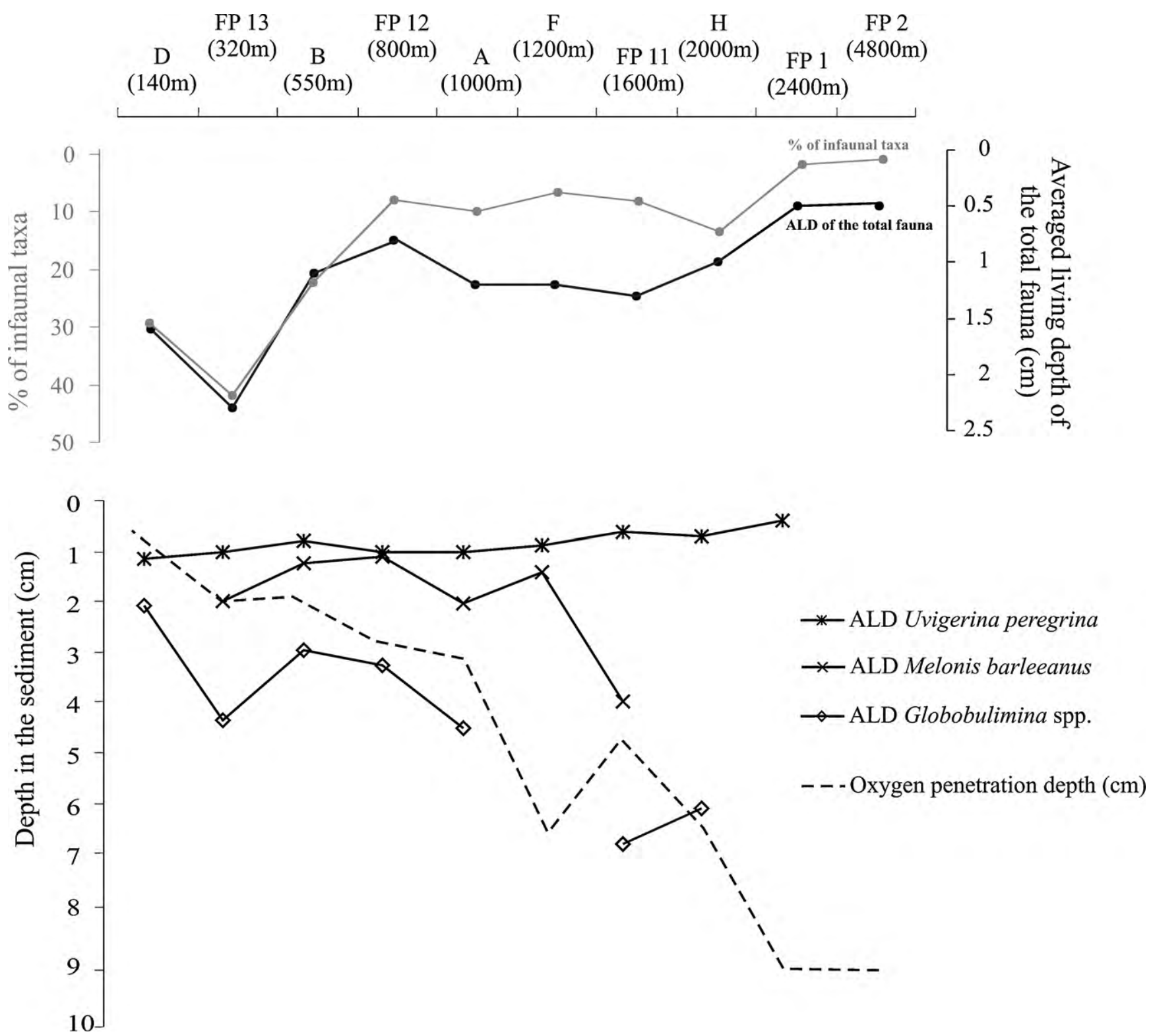

Fig. 6. Upper panel: $\mathrm{ALD}_{10}$ of the total live fauna along the 10-stations bathymetric transect and cumulative percentages of infaunal taxa occurring with more than $5 \%$ in at least one station (C. oolina, Globobulimina spp., G. orbicularis, M. barleeanus, N. fabum and U. elongastriata). Lower panel: oxygen penetration depth into the sediment and $\mathrm{ALD}_{10}$ of three important species presenting the three main microhabitats found in the Bay of Biscay.

Partie supérieure: $A L D_{10}$ de la faune vivante totale au niveau des 10 stations du transect bathymétrique, ainsi que les pourcentages cumulatifs des taxons endopéliques présents à $\geq 5 \%$ dans au moins une station (C. oolina, Globobulimina spp., G. orbicularis, M. barleeanus, N. fabum et U. elongastriata). Partie inférieure : pénétration d'oxygène dans le sédiment et $A L D_{10}$ de trois espèces importantes représentant les trois principaux microhabitats dans les sédiments du Golfe de Gascogne.

faunas decreases in function of water depth and oxygen penetration depth, logically revealing a strong correlation between the two parameters as well. It appears that both the density of the foraminiferal faunas and oxygen penetration depth into the sediment respond clearly to the diminishing flux of metabolisable organic carbon towards deeper waters. In the following paragraphs, we will therefore use both parameters to characterise the trophic level of our stations in a qualitative way.

On the basis of the total densities of the live foraminiferal faunas, and oxygen penetration depth into the sediment, we can differentiate 4 trophic zones along our sampling transect:
- at the shallowest station D (140 m), located at the outer continental shelf of the Bay of Biscay, live benthic foraminifera are present with very high densities $\left(1430 \pm 939 \mathrm{ind} . / 50 \mathrm{~cm}^{2}\right)$ and the oxygen penetration depth in the sediment is minimal $(\sim 0.5 \mathrm{~cm})$. At this station, important differences between densities recorded during different sampling periods reflect the seasonal variation of organic matter deposition (Langezaal et al., 2006). This zone seems to present the most eutrophic conditions along the bathymetric transect;

- at the upper slope stations between 320 and $1000 \mathrm{~m}$ depth (FP13, B, FP12, A), live benthic foraminifera are present with 
Table 3

Average Living Depth $\left(\mathrm{ALD}_{10}\right)$ of the main foraminiferal species (present with $\geq 5 \%$ in at least one station) at the ten stations of the bathymetric transect. Between parentheses is indicated the number of individuals on which the calculation is based. An averaged value is given for stations D, B and A that were sampled at several periods.

ALD 10 des espèces vivantes majoritaires (présentes à $\geq 5 \%$ dans au moins une station) au niveau des 10 stations. Le nombre d'individus utilisé pour les calculs est indiqué entre parenthèses. Une valeur moyenne est donnée pour les stations $D, B$ et A ayant été échantillonnées à plusieurs périodes.

\begin{tabular}{|c|c|c|c|c|c|c|c|c|c|c|}
\hline Stations & D & FP13 & $\mathrm{B}$ & FP12 & A & $\mathrm{F}$ & FP11 & $\mathrm{H}$ & FP1 & FP2 \\
\hline Depth (m) & 140 & 320 & 550 & 800 & 20550 & 320550 & 1600 & 4800 & 2400 & 4800 \\
\hline \multicolumn{11}{|l|}{ Perforates } \\
\hline Bolivina subaenariensis & $0.8(651)$ & $2.8(1)$ & $4.5(1)$ & & & & & & & \\
\hline Bulimina alazanensis & & & & & & & & & $0.5(19)$ & \\
\hline Bulimina inflata & & & & & $1.1(7)$ & $0.1(1)$ & $0.5(7)$ & $0.5(3)$ & $0.3(10)$ & \\
\hline Chilostomella oolina & $1.3(223)$ & $4.8(37)$ & $3.0(7)$ & & & & & $6.5(1)$ & & \\
\hline Cibicidoides kullenbergi & & & & & & & $0.5(80)$ & & $0.8(3)$ & \\
\hline Cibicidoides robertsonianus & & & & & $0.4(1)$ & $1.4(8)$ & $0.8(11)$ & & & \\
\hline Gavelinopsis translucens & & & $0.1(1)$ & & & $2(0.1)$ & $0.3(15)$ & $0.9(4)$ & $0.3(8)$ & \\
\hline Globobulimina spp. & $2.1(6)$ & $4.6(84)$ & $2.9(37)$ & $3.1(2)$ & $3.1(2)$ & $7.5(1)$ & $2.9(37)$ & $6.1(5)$ & & \\
\hline Gyroidina orbicularis & & $0.3(1)$ & $0.9(2)$ & $1.0(2)$ & $2.2(9)$ & & $1.5(15)$ & $1.3(1)$ & $0.6(3)$ & $1.3(1)$ \\
\hline Hoeglundina elegans & $1.7(6)$ & & & $1.0(1)$ & $0.8(42)$ & $0.5(12)$ & $0.3(68)$ & $0.6(58)$ & $0.3(9)$ & \\
\hline Melonis berleeanus & & $2.0(66)$ & $1.2(53)$ & $1.1(7)$ & $1.9(13)$ & $1.4(7)$ & $4.0(6)$ & & & \\
\hline Melonis pompilioides & & & & & & & & & & $0.3(7)$ \\
\hline Nonion fabum & $2.4(366)$ & & $1.3(1)$ & & & & & & & \\
\hline Nuttallides umboniferus & & & $0.9(3)$ & & $0.6(9)$ & & & & $0.3(3)$ & $0.5(18)$ \\
\hline Uvigerina elongatastriata & & $2.3(14)$ & $1.5(31)$ & & $1.3(1)$ & & & & & \\
\hline Uvigerina mediterranea & & $1.4(18)$ & $0.8(180)$ & $0.7(67)$ & $0.9(96)$ & $0.2(3)$ & & & & \\
\hline Uvigerina peregrina & $1.2(43)$ & $1.0(2)$ & $0.8(54)$ & $1.0(2)$ & $0.9(94)$ & $0.9(41)$ & $0.6(22)$ & $0.7(44)$ & $0.9(94)$ & \\
\hline Valvulineria bradyana & $0.9(210)$ & & & & & & & & & \\
\hline \multicolumn{11}{|l|}{ Porcellaneous } \\
\hline Pyrgo elongata & & $1.5(9)$ & & & & & $0.6(14)$ & & & \\
\hline Quinqueloculina sp. 1 & $1.2(15)$ & & $0.3(2)$ & & $0.5(1)$ & $0.3(7)$ & $0.3(2)$ & $0.9(1)$ & & $0.6(9)$ \\
\hline \multicolumn{11}{|l|}{ Fossilizing agglutinates } \\
\hline Bigenerina nodosaria & & $0.7(95)$ & $0.5(7)$ & & & & & & & \\
\hline Eggerella bradyi & & & & & $0.8(3)$ & & $0.7(6)$ & & $0.6(6)$ & $0.5(29)$ \\
\hline \multicolumn{11}{|l|}{ Non-fossilizing agglutinates } \\
\hline Ammobaculites agglutinans & & & & & $0.7(15)$ & & & & $0.3(11)$ & $0.4(3)$ \\
\hline Clavulina cylindrica & $1.0(105)$ & $1.5(18)$ & $1.3(18)$ & & & & & & & \\
\hline Cribrostomoides spp. & $0.9(2)$ & & $0.8(27)$ & $0.7(10)$ & $0.8(8)$ & $2.1(4)$ & $1.9(12)$ & $2.1(4)$ & $0.4(3)$ & $0.4(3)$ \\
\hline Lagenammina pseudodifflugiform is & & & & & $1.0(27)$ & & & & & \\
\hline Psammosphaera spp. & & $0.3(4)$ & $0.5(2)$ & $0.3(9)$ & $1.4(4)$ & & & & & \\
\hline Reophax dentaliniformis & & $2.6(2)$ & $1.6(2)$ & & & & $0.9(3)$ & & $0.9(9)$ & $1.3(2)$ \\
\hline$A L D_{10}$ of the entire fauna & 1.6 & 2.3 & 1.21 & 0.8 & 1.2 & 1.2 & 1.3 & 1 & 0.5 & 0.5 \\
\hline
\end{tabular}

high densities (more than 300 ind. $/ 50 \mathrm{~cm}^{2}$ except at station FP12) and the oxygen penetration depth is varying from 1.9 to $2.8 \mathrm{~cm}$. This zone seems to present eutrophic conditions, but less pronounced than at station $\mathrm{Dl}$;

- at the mid to lower slope stations, between 1200 and $2000 \mathrm{~m}$ depth $(\mathrm{F}, \mathrm{FP} 11, \mathrm{H})$, the oxygen penetration depth varies from 4.5 to $6.3 \mathrm{~cm}$. Live foraminiferal faunas present densities around $100 \mathrm{ind} . / 50 \mathrm{~cm}^{2}$. We consider this zone as mesotrophic;

- at the stations deeper than $2000 \mathrm{~m}$ (FP1 and FP2), the oxygen penetration depth is 8 to $9 \mathrm{~cm}$. Live foraminifera are present with very low densities $\left(<50\right.$ ind. $\left./ 50 \mathrm{~cm}^{2}\right)$. We consider this zone as oligotrophic.

These observations agree with several earlier studies (e.g., Douglas, 1981; Altenbach and Sarthein, 1989; Gooday, 1993; Jorissen et al., 1998). However, many authors assume that each single species has specific requirements with respect to the quantity and quality of organic supplies (Rathburn and Corliss, 1994; Altenbach et al., 1999; Fontanier et al., 2002).

\subsection{Trophic dependencies of individual taxa}

Several authors have suggested a critical threshold of total organic flux under which the majority of "eutrophic" species disappear and the assemblages become dominated by other species, more adapted to oligotrophic conditions (Altenbach et al., 1999; Jian et al., 1999; Morigi et al., 2001). In Fig. 7, we plotted the distribution of the main species along our bathymetric transect, together with curves of faunal density and oxygen penetration, which we use as qualitative indicators of the trophic level of the environment. It should of course be kept in mind that other environmental parameters than organic input alone, could have an impact on the depth distribution of the various species. 


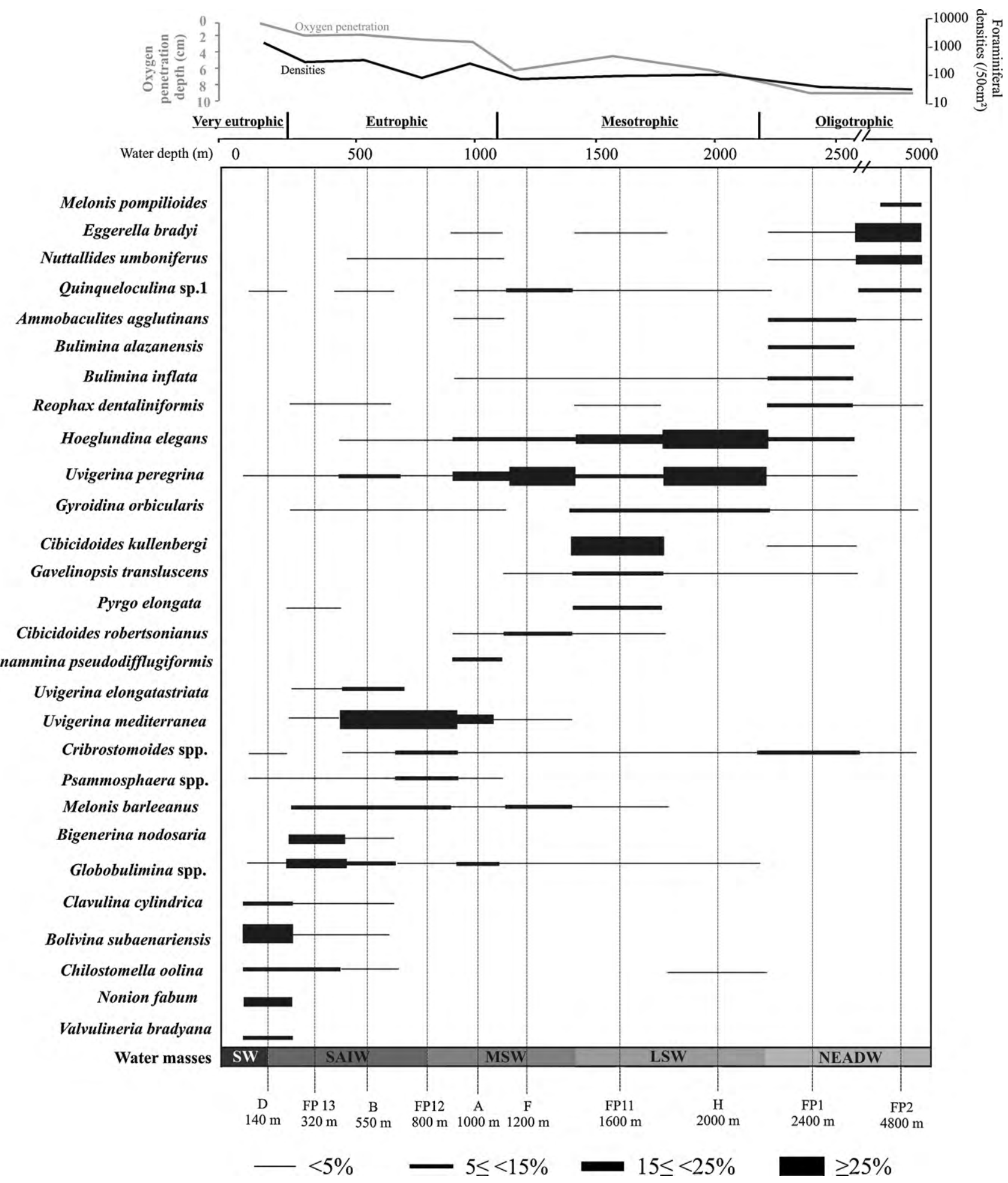

Fig. 7. Relative densities of the important live foraminiferal taxa (present with percentage higher than $5 \%$ in at least one station) along the 10 -stations bathymetric transect.

Densités relatives des espèces majoritaires vivantes (présentes à $\geq 5 \%$ dans au moins une station) au niveau des 10 stations du transect bathymétrique.

For instance, until the early 1980s, the benthic foraminiferal assemblages were thought to mainly reflect the water mass characteristics where they are found (e.g., Streeter, 1973; Lutze, 1979; Caralp, 1987). Nowadays, many scientists doubt the validity of the so-called "water mass concept" (Jorissen et al., 2007). Our data clearly suggest that in our study area, species occur- rences are not related to water masses. In fact, none of the dominant species is restricted to a single water mass (Fig. 7). The main species appear to be distributed according to different trophic conditions. On the basis of the information summarised in Fig. 7, we can separate the species (see the taxonomic reference list in Appendix F) into the following categories: 
- the first group of species appears to be associated with highly eutrophic conditions: Bolivina subaenariensis is strongly dominant at the shallowest station D $(140 \mathrm{~m})$ and is nearly absent or absent at the other stations. In a previous study on the seasonal variability of foraminiferal faunas at this $140 \mathrm{~m}$ deep station (Langezaal et al., 2006), this species has been qualified as a shallow infaunal species, fairly tolerant of low oxygen values and able to react to high food concentrations with rapid growth. Valvulineria bradyana and Nonion fabum are only present at station D $(140 \mathrm{~m})$. In the Adriatic Sea, Jorissen (1987) describes a minimum water depth of $40 \mathrm{~m}$ for $V$. bradyana, at the outer part of the organic carbon enriched clay belt. In a more recent study, this taxon seems to combine a preference for high quality resources, a high competitiveness and perhaps a high tolerance for anoxic conditions (Fontanier et al., 2002). It settles together with $N$. fabum (=N. scaphum in Fontanier et al., 2002) in strongly suboxic and anoxic layers slightly deeper in the sediment. Chilostomella oolina is well represented in the live faunal assemblages at stations D $(140 \mathrm{~m})$ and FP13 $(320 \mathrm{~m})$; it is present with very low proportions at stations $\mathrm{B}(550 \mathrm{~m})$ and $\mathrm{H}(2000 \mathrm{~m})$ and is totally absent at the other stations. In the literature, $C$. oolina has been described as an intermediate or deep infaunal species which is well adapted to suboxic conditions (Corliss and Emerson, 1990; Bernhard, 1992; Rathburn and Corliss, 1994; Jorissen et al., 1998; Licari et al., 2003). In these stressed environments, this taxon appears to have a competitive advantage over more superficially living taxa (Rathburn and Corliss, 1994). Clavulina cylindrica is present only between stations $\mathrm{D}(140 \mathrm{~m})$ and $\mathrm{B}(550 \mathrm{~m})$ in the study area with very rather low relative frequencies;

- the second group of species appears to be associated with eutrophic conditions: Uvigerina mediterranea dominates the live assemblages between stations B $(550 \mathrm{~m})$ and A $(1000 \mathrm{~m})$ with a maximal relative frequency at station FP12 (800 m). Its proportion diminishes at station FP13 $(320 \mathrm{~m})$ and station F $(1200 \mathrm{~m})$. This species is totally absent at all stations below $1200 \mathrm{~m}$. De Rijk et al. (2000) suggest an inferior limit of about $2.5 \mathrm{~g}$ labile organic C. $\mathrm{m}^{-2} \cdot \mathrm{yr}^{-1}$ whereas Altenbach et al. (1999) observe a maximal abundance around $10 \mathrm{~g}$ total organic C. $\mathrm{m}^{-2} \cdot \mathrm{yr}^{-1}$. Uvigerina elongatastriata is present only at stations FP13 $(320 \mathrm{~m})$ and B $(550 \mathrm{~m})$, with much lower percentages than U. mediterranea. Melonis barleeanus is found between stations FP13 (320 m) and FP11 (1600 m). Its maximal relative abundance is recorded at station FP13 $(320 \mathrm{~m})$. In the literature, this species is generally associated with important amounts of organic matter in deep sea environments (e.g., Lutze and Coulbourn, 1984; Mackensen et al., 1985; Corliss and Chen, 1988; Caralp, 1989; Jorissen et al., 1995; Fontanier et al., 2002). Globobulimina spp. is present with very low proportions between stations FP13 (320 m) and $\mathrm{H}(2000 \mathrm{~m})$. Percentages above $5.0 \%$ are only recorded between stations FP13 $(320 \mathrm{~m})$ and A $(1000 \mathrm{~m})$. This species has been described in various high productivity areas (e.g., Altenbach, 1985; Fariduddin and Loubere, 1997). A recent study (Risgaard-Petersen et al., 2006) indicates that Globobulimina pseudospinescens, and possibly many other infaunal taxa, are able to store, and to respire nitrates, allowing them to live in anoxic sediments for prolonged periods of time. It is very probable that $G$. pyrula has a similar adaptation (Larkin and Gooday, 2009). Also the agglutinated species Lagenammina pseudodifflugiformis, Bigenerina nodosaria and Psammosphaera spp. seem to prefer eutrophic areas in the Bay of Biscay. In fact, L. pseudodifflugiformis is only present alive at station A $(1000 \mathrm{~m})$ with relatively low percentages. B. nodosaria is dominant at station FP13 $(320 \mathrm{~m})$ and nearly disappears at station B (550 m). Psammosphaera spp. is present with percentages greater than $5.0 \%$ only at station FP12 $(800 \mathrm{~m})$. At the other stations, this species accounts for less than $1.0 \%$ of the total fauna. Cribrostomoides spp. is present at nearly all stations with very low percentages. Percentages above $5.0 \%$ are only recorded at stations FP12 $(800 \mathrm{~m})$ and FP1 $(2400 \mathrm{~m})$. This species does not show a very clear trophic preference;

- the third group of species is more or less limited to sites with conditions which we consider as mesotrophic: Uvigerina peregrina has a wide distribution, between stations FP13 $(320 \mathrm{~m})$ and FP1 $(2400 \mathrm{~m})$. This species is abundant at stations $\mathrm{A}(1000 \mathrm{~m}), \mathrm{F}(1200 \mathrm{~m})$ and $\mathrm{H}(2000 \mathrm{~m})$ and present in fair numbers at stations B $(550 \mathrm{~m})$, FP11 $(1600 \mathrm{~m})$ and FP1 $(2400 \mathrm{~m})$. In the literature, this species has been described in areas with high organic fluxes (Lutze, 1980; Altenbach and Sarthein, 1989; Licari et al., 2003; Schönfeld, 2006). Altenbach et al. (1999) describe it at sites with estimated carbon organic fluxes from 2 to $20 \mathrm{gC} . \mathrm{m}^{-2} \cdot \mathrm{yr}^{-1}$ (Altenbach et al., 1999), with a maximum between 5 and 9 $\mathrm{gC} . \mathrm{m}^{-2} \cdot \mathrm{yr}^{-1}$. The studies of Lutze (1986), Van Leeuwen (1986) and Schönfeld (2006) underline the existence of a large morphological variability in this taxon, with the different morphotypes having different dependencies on organic flux levels. These different morphotypes, which very probably have different ecological requirements, can be distinguished as distinct species or subspecies, or rather be differentiated as morphotypes within a single species. In our study area, we find a gradual transition from typical peregrina-types (pl. 1, Figs. 1-6 in Lutze, 1986) at the deeper sides, to parva-types (pl. 3, Figs. 1-5 in Lutze, 1986) at the shallower sites where $U$. peregrina occurs. Because of the very gradual transition between the two morphotypes, without a sharp break, we decided not to count them separately. Hoeglundina elegans is very abundant at stations FP11 (1600 m) and H $(2000 \mathrm{~m})$ and occurs with fair proportions at stations A $(1000 \mathrm{~m}), \mathrm{F}$ $(1200 \mathrm{~m})$ and FP1 $(2400 \mathrm{~m})$. In the literature, this species is often described as typical of low organic carbon areas (Lutze and Coulbourn, 1984; Corliss, 1985; Corliss and Emerson, 1990; Corliss, 1991; Fontanier et al., 2002; Morigi et al., 2001). Cibicidoides kullenbergi is particularly abundant at station FP11 (1600 m) and is present with a low percentage at station FP1 (2400 m). Altenbach et al. (1999) record it in an area with an estimated total carbon organic flux of 1.8 to 3.8 $\mathrm{gC} \cdot \mathrm{m}^{2} \cdot \mathrm{yr}^{-1}$. Fariduddin and Loubere (1997) and Schmiedl et al. (1997) suggested that the ecological requirements of this species are very similar to those of Hoeglundina elegans. Gavelinopsis translucens is relatively well represented 
between stations F (1200 m) and FP1 (2400 m), Cibicidoides robertsonianus is only present at stations F (1200 m) and FP11 (1600 m), Gyroidina orbicularis is present with significant percentages only between stations FP11 (1600 m) and H (2000 m), whereas Pyrgo elongata is present with 5.0\% of the live assemblages at station FP11 (1600 m). In the Bay of Biscay, all these species seems to prefer mesotrophic settings;

- the fourth group contains species that are associated with the most oligotrophic conditions found along our transect: Bulimina alazanensis is only found at station FP1 (2400 m) where it dominates the live fauna. In the south Atlantic, this species is found in significant numbers between 1600 and $3700 \mathrm{~m}$ (Schmiedl et al., 1997). Nuttallides umboniferus dominates the fauna at station FP2 $(4800 \mathrm{~m})$ is present with very low percentages at stations FP1 $(2400 \mathrm{~m})$, A $(1000 \mathrm{~m})$ and B $(550 \mathrm{~m})$. Schmiedl et al. (1997) ascribed its abundance in the abyssal part of the South Atlantic Ocean to a preference for oligotrophic settings. Eggerella bradyi is an agglutinated species which is particularly abundant at station FP2 $(4800 \mathrm{~m})$. At the other stations where it is found (FP1, $2400 \mathrm{~m}$; FP11, $1600 \mathrm{~m}$ and A, $1000 \mathrm{~m}$ ), its relative proportion does not exceed 4.0\%. Ammobaculites agglutinans and Reophax dentaliniformis present both maximal abundances at FP1 $(2400 \mathrm{~m})$. R. dentaliniformis has a wider distributional area. It is found between stations FP13 $(320 \mathrm{~m})$ and FP2 $(4800 \mathrm{~m})$ but with proportions less than $2.0 \%$. In general, a dominance of agglutinated species reflects the oligotrophic character of the benthic ecosystem (Jorissen et al., 1998). Melonis pompilioides is only present at station FP2 at $4800 \mathrm{~m}$ water depth. This species is always found at great water depths (Lutze, 1980; Harloff and Mackensen, 1997; Jorissen et al., 1998). Quinqueloculina sp. 1 is present at nearly all stations, generally with very low abundances. However, its maximal density is recorded at station FP2 (4800 m). Bulimina inflata is present between stations B $(550 \mathrm{~m})$ and FP2 $(4800 \mathrm{~m})$ with a maximum at station FP1 $(2400 \mathrm{~m})$. B. inflata is a shallow infaunal surface dweller (Corliss, 1985, 1991; Mackensen and Douglas, 1989; Corliss and Emerson, 1990; Rathburn et al., 1996; Fontanier et al., 2002) which may reflect well oxygenated microenvironments and/or the presence of labile organic carbon deeper in the sediment. According to other studies, B. inflata appears to prefer slightly more eutrophic conditions, such as those encountered in the mid-slope environments under the very productive surface waters off Cape Blanc, NW Africa (Jorissen et al., 1998; Morigi et al., 2001). It is possible that this apparently contradictory evidence is caused by the fact that forms which are genetically different, but morphologically similar, have been lumped within the same species.

The evolution of the species composition of the foraminiferal faunas along the bathymetric transect confirms the general picture of decreasing organic fluxes from the continental shelf to the abyssal area in the Bay of Biscay; we observe high densities of species typical of eutrophicated environments at the shallower stations, that are gradually replaced by species typical of oligotrophic settings in the abyssal area. It appears that most species have indeed a pronounced preference for a certain trophic level, or a specific organic flux range. Within the range of optimal trophic conditions, the species is highly competitive, and may attain high densities, and consequently, elevated percentages. Beyond critical upper and/or lower threshold values, species rapidly become less competitive. They are therefore "replaced" by other taxa, which are better adapted and more competitive in the trophic conditions in this domain. Koho et al. (2008) observe relatively similar trend in the distribution of abundant taxa in the Portuguese margin.

Although the quantity of organic carbon appears to be important to explain the foraminiferal distributional patterns in the Bay of Biscay, many studies suggest also a strong linkage between faunal characteristics and the quality (reactivity) of the organic matter arriving at the sea floor (e.g., De Rijk et al., 2000; Koho et al., 2007; Mojtahid et al., 2009). It is the relatively more labile organic carbon which is remineralised. Unfortunately, due to a lack of information on organic matter quality, this factor could not be considered in this study. Also, our study does not integrate the short term variability of the standing stocks and of the composition of the foraminiferal faunas in response to interannual and seasonal primary production oscillations and the ensuing organic fluxes to the sea floor. The densities of some very reactive opportunistic species, such as Uvigerina peregrina and Epistominella exigua, appear to depend strongly on the supplies of highly reactive organic carbon (e.g., Gooday, 1993; Fontanier et al., 2003, 2006). Their density is probably not representative for an average annual organic flux level, but is rather determined by the appearance of pulsed organic matter flux events in the weeks to month before sampling. This appears to be due to their capability to rapidly adapt to changing trophic conditions (Gooday and Lambshead, 1989; Ohga and Kitazato, 1997; Kitazato et al., 2000; Jorissen et al., 2007).

\subsection{Microhabitats}

According to the TROX-model (Jorissen et al., 1995), proposed for open marine benthic foraminiferal faunas, shallow infaunal foraminifera profit from labile organic matter supplies in the well oxygenated niches around the sediment-water interface, whereas deep infaunal foraminifera may survive in strongly hypoxic, or even anoxic sediments (e.g., Bernhard and Reimers, 1991; Bernhard, 1992; Moodley and Hess, 1992; Bernhard et al., 1997), where labile organic particles are scarce (Koho et al., 2008). Most species are able to change their microhabitat in response to food supply and to dissolved oxygen concentration in the bottom and pore waters (Linke and Lutze, 1993; Jorissen et al., 1995). In food-limited environments (oligotrophic environments), commonly characterised by well oxygenated bottom waters, both foraminiferal standing stock and diversity are rather low and the fauna mainly comprises shallow infaunal taxa. In mesotrophic environments, standing stocks are moderately high and the faunal assemblages comprise a variety of shallow, intermediate and deep infaunal species, which show a vertical succession in topmost $5 \mathrm{~cm}$ of the sediment. Finally, in eutrophic and oxygen limited environments, low diversity faunas with high standing stocks prevail, often mainly composed of infaunal 


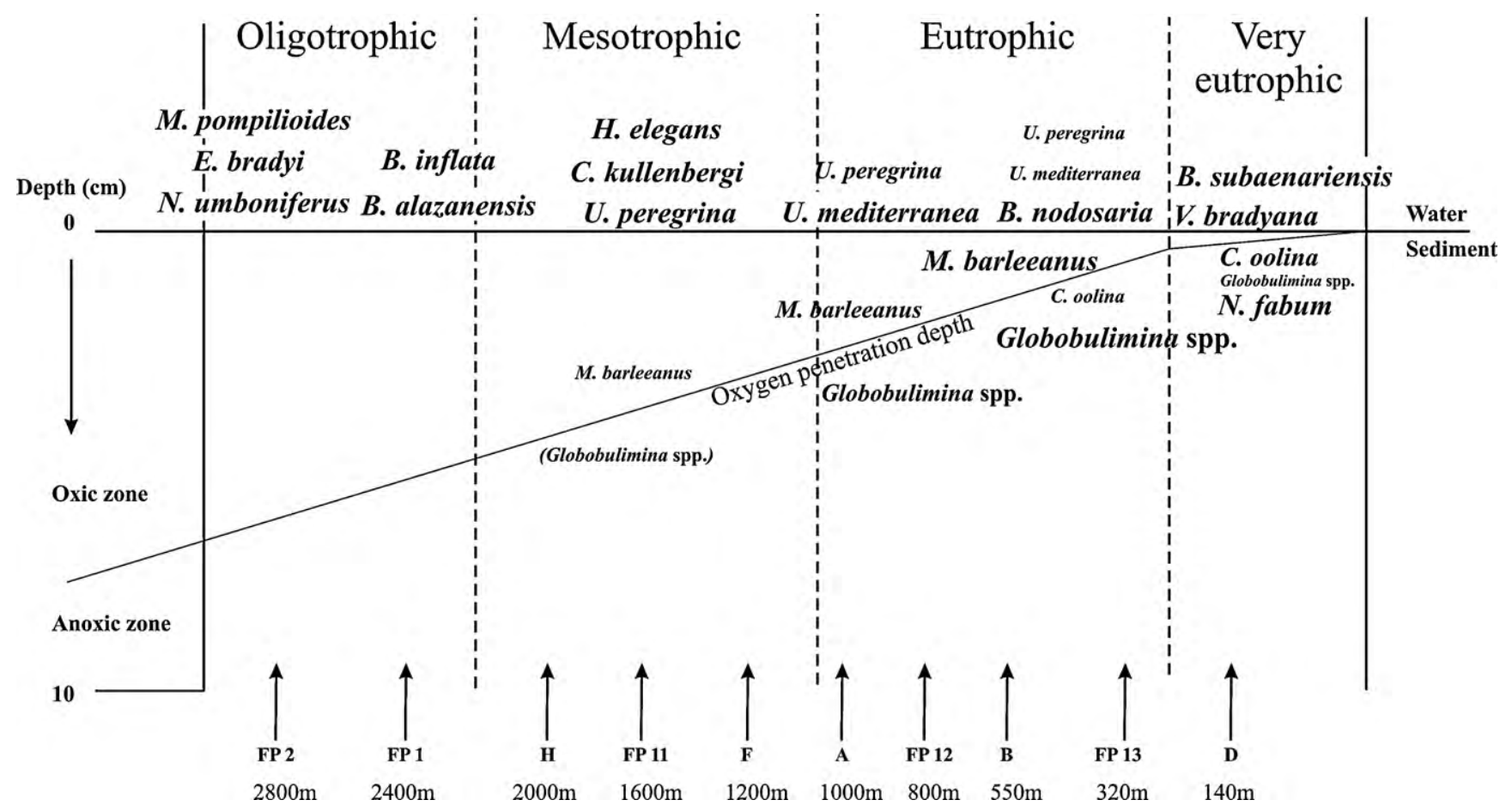

Fig. 8. Microhabitat distribution and specific foraminiferal composition along the bathymetric transect in the Bay of Biscay; the approximate position of our 10 stations is indicated (see text for full explanation). The species written in large font character represent the taxa that are very abundant and largely dominate the faunas. The species written in smaller font are still dominant but occur in lower proportions.

Microhabitat et composition des foraminifères vivants le long du transect bathymétrique dans le Golfe de Gascogne; la position approximative des 10 stations est indiquée (voir texte pour l'explication complète). Les espèces figurées en grand caractère sont les espèces abondantes et largement dominantes; celles figurant en petit caractère restent dominantes mais sont présentes avec des plus faibles proportions.

species that are adapted to strongly dysoxic conditions (Jorissen et al., 1995), which are found close to the sediment-water interface here. In such environments, the vertical species succession is often strongly compressed, and taxa which elsewhere occupy deep infaunal niches may be found close to, or at the sediment surface.

At all our stations, the live faunas are strongly concentrated in the first $\mathrm{cm}$ of the sediment, suggesting a strong dependence on the flux of labile, easily consumable organic matter. Despite the strong faunal concentration in the first $\mathrm{cm}$, the $\mathrm{ALD}_{10}$ of the total faunas is not uniform: 1.6 and $2.3 \mathrm{~cm}$ for the relatively shallow stations D and FP13, between 0.8 and $1.3 \mathrm{~cm}$ for the intermediate stations (B, FP12, A, F, FP11 and H) and $0.5 \mathrm{~cm}$ for the deepest stations FP1 and FP2. The deepening of the ALD 10 for the total fauna at station FP13 is mainly the result of the high abundance of intermediate (e.g., Melonis barleeanus) and deep infaunal species (Globobulimina spp. and Chilostomella oolina). The very shallow $\mathrm{ALD}_{10}$ of the deepest stations (FP1 and FP2) is mainly caused by the scarcity of deep infaunal species.

Fig. 8 synthesises the spatial and microhabitat distribution of live benthic foraminifera along the bathymetric/trophic transect: The shallower station $\mathrm{D}$, described in detail by Langezaal et al. (2006), is characterised by very high foraminiferal densities that are largely restricted to the upper $3 \mathrm{~cm}$ of the sediment. Apparently this fauna reflects a very high labile organic carbon flux. Valvulineria bradyana and Bolivina subaenariensis dominate the first half $\mathrm{cm}$. Chilostomella oolina and Globobulimina spp. settle together with Nonion fabum in strongly suboxic and anoxic sediments down to $3 \mathrm{~cm}$ depth. A major faunal change takes place at station FP13 $(320 \mathrm{~m})$, i.e. the intermediate between $\mathrm{D}(140 \mathrm{~m})$ and $\mathrm{B}(550 \mathrm{~m})$. This station is characterized by the disappearance of $N$. fabum and $V$. bradyana and the appearance of the uvigerinids ( $U$. mediterranea, U. elongastriata and $U$. peregrina). At this station, the deepest $\operatorname{ALD}_{10}(2.3 \mathrm{~cm})$ is recorded. The intermediate (M. barleeanus) and deep infaunal (Globobulimina spp.) taxa, found fairly close to the sediment surface at station $\mathrm{D}$, are living deeper in the sediment here. The almost complete separation between superficial and deeper infaunal species (Fig. 5) is probably due to a deeper penetration of oxygen into the sediment and an expanded succession of the successive redox zones. Towards deeper sites, until about $2000 \mathrm{~m}$ water depth, the surface faunas are dominated by uvigerinids. The proportion of deep infaunal species strongly decreases whereas their microhabitat deepens. This appears to reflect a progressive decrease of organic carbon fluxes and a progressively deeper position of the oxygen penetration limit. The appearance of more oligotrophic shallow infaunal taxa, such as H. elegans, $N$. umboniferus and $C$. kullenbergi shows the influence of the gradually decreasing organic flux towards deeper areas. The combination of the progressive disappearance of deep infaunal taxa and the increasing proportion of shallow infaunal species leads to a lower $\mathrm{ALD}_{10}$ of the total fauna at these stations. A critical threshold of organic flux is attained between station $\mathrm{H}$ $(2000 \mathrm{~m})$ and FP1 $(2400 \mathrm{~m})$. In fact, between those two sta- 
tions, the $\mathrm{ALD}_{10}$ of the total live foraminiferal fauna decreases from about $1 \mathrm{~cm}$ at station $\mathrm{H}$ to about $0.5 \mathrm{~cm}$ at station FP1. This is mainly caused by the nearly total disappearance of deep and intermediate infaunal taxa, indicative of a total absence of exploitable resources deeper in the sediment. The low quantities of organic matter arriving at the sea floor appear to be completely consumed in the superficial sediment; the deep infaunal species are inhibited by the insufficient food supply to deeper sediment layers.

\section{Conclusions}

The foraminiferal and geochemical study of five supplementary stations located at $320 \mathrm{~m}, 800 \mathrm{~m}, 1600 \mathrm{~m}, 2400 \mathrm{~m}$ and $4800 \mathrm{~m}$ water depth reinforce the main distributional trends predicted by the TROX-model. According to the spatial and vertical distributional patterns of foraminifera, we can divide the bathymetrical transect in the Bay of Biscay into four zones. Each zone is characterised by a specific faunal density range, species composition, and microhabitat distribution:

- at the outer shelf, faunas are particularly rich, dominated by Bolivina subaenariensis and Valvulineria bradyana, and the succession of microhabitat zones is strongly compressed;

- at the upper slope, faunas are still very rich, dominated by uvigerinids, and the deep infauna is well developed; faunal penetration into the sediment is maximal;
- at the mid and lower slope, faunas become poorer, and are dominated by Cibicidoides kullenbergi and Hoeglundina elegans. Scarce deep infaunal taxa occur at a maximum depth in the sediment;

- at the lower slope and on the abyssal plane, faunas are very poor, dominated by Nuttallides umboniferus and Melonis pompilioides. The fauna is limited to the sediment surface. Intermediate and deep infaunal taxa are absent.

\section{Acknowledgements}

We thank the crews of Côte de la Manche and RV Atalante for their help during the sampling cruises, the technical assistance of Melissa Gaultier and Yingwei Xie, who participated in data processing. This work has been carried out in the framework of the French FORAMPROX project, financed by PNEDC and PROOF. We are grateful to C. Morigi and a second anonymous reviewer, who dedicated much time in the correction of the first manuscript, leading to a strongly improved final version.

Appendix A. Census data (non-standardized) of live benthic foraminifera at station FP13. All numbers are based on the study of one interface core with $a \sim 71 \mathrm{~cm}^{2}$ surface area

Données non standardisées des foraminifères vivants à la station FP13 basées sur l'étude d'une carotte de $\sim 71 \mathrm{~cm}^{2}$ de surface

\begin{tabular}{|c|c|c|c|c|c|c|c|c|c|c|c|c|c|c|c|c|}
\hline \multicolumn{17}{|l|}{ Station FP13 } \\
\hline Sediment level $(\mathrm{cm})$ & $0-0.5$ & $0.5-1$ & $1-1.5$ & $1.5-2$ & $2-2.5$ & $2.5-3$ & $3-3.5$ & $3.5-4$ & $4-5$ & $5-6$ & $6-7$ & $7-8$ & $8-9$ & $9-10$ & Total & $\%$ \\
\hline \multicolumn{17}{|l|}{ Perforates } \\
\hline Amphicoryna scalaris & 3 & 4 & 3 & 1 & & & & & & & & & & & 11 & 2.27 \\
\hline Bolivina alata & & & 1 & 9 & 4 & 2 & 3 & & & & & & & & 19 & 3.92 \\
\hline Bolivina striatula & & 1 & 1 & & 1 & & 1 & & & 2 & & & & & 6 & 1.24 \\
\hline Bolivina subaenariensis & & & & & & 1 & & & & & & & & & 1 & 0.21 \\
\hline Bolivinata quadrilatera & & 2 & & & & & & & & & & & & & 2 & 0.41 \\
\hline Bulimina aculeata & & & & 1 & 1 & 2 & 2 & 1 & & & & & & & 7 & 1.44 \\
\hline Bulimina costata & & 2 & & 1 & & & & & & & & & & & 3 & 0.62 \\
\hline Bulimina marginata & & 1 & & 1 & & & & & & & & & & & 2 & 0.41 \\
\hline Cancris auriculus & & & & & & & & & 1 & & & & & & 1 & 0.21 \\
\hline Cassidulina carinata & 1 & & & & & & & & & & & & & & 1 & 0.21 \\
\hline Chilostomella oolina & & & & & & 1 & 2 & 2 & 22 & 5 & 3 & 1 & 1 & & 37 & 7.63 \\
\hline Cibicidoides pachydermus & 2 & & & & & & & & & & & & & & 2 & 0.41 \\
\hline Dentalina bradyensis & & 1 & 1 & & 1 & 2 & & & & & & & & & 5 & 1.03 \\
\hline Dentalina submaciata & & 1 & & 1 & & & & & & & & & & & 2 & 0.41 \\
\hline Globobulimina spp. & 2 & 2 & 3 & 2 & 4 & 1 & 4 & & 23 & 29 & 12 & 2 & & 1 & 85 & 17.53 \\
\hline Gyroidina orbicularis & 1 & & & & & & & & & & & & & & 1 & 0.21 \\
\hline Hanzawaia boueana & 3 & & & & & & & & & & & & & & 3 & 0.62 \\
\hline Hyalinea balthica & & 2 & & & & & & & & & & & & & 2 & 0.41 \\
\hline Lenticulina peregrina & 3 & 1 & & & & & & & & & & & & & 4 & 0.82 \\
\hline Melonis barleeanus & 3 & 7 & 21 & 8 & 14 & 4 & 3 & 1 & 2 & & 2 & 1 & & & 66 & 13.61 \\
\hline Nonionella turgida & & & & & & & 1 & & 2 & & & & & & 3 & 0.62 \\
\hline Pullenia quinqueloba & & & & 1 & 1 & & & & & & & & & & 2 & 0.41 \\
\hline Rosalina sp. & & 1 & & 1 & & & & & & & & & & & 2 & 0.41 \\
\hline Spheroidina bulloides & & & & & & & 1 & & & & & & & & 1 & 0.21 \\
\hline Trifarina bradyi & 1 & & & & & & & & & & & & & & 1 & 0.21 \\
\hline Uvigerina elongatastriata & & 1 & 1 & 1 & 6 & 4 & 1 & & & & & & & & 14 & 2.89 \\
\hline Uvigerina mediterranea & 5 & 3 & 3 & & 4 & 3 & & & & & & & & & 18 & 3.71 \\
\hline Uvigerina peregrina & 1 & & & 1 & & & & & & & & & & & 2 & 0.41 \\
\hline Indet. & & 1 & & & & & & & & & & & & & 1 & 0.21 \\
\hline
\end{tabular}


Appendix A (Continued)

\begin{tabular}{|c|c|c|c|c|c|c|c|c|c|c|c|c|c|c|c|c|}
\hline \multicolumn{17}{|l|}{ Station FP13 } \\
\hline Sediment level $(\mathrm{cm})$ & $0-0.5$ & $0.5-1$ & $1-1.5$ & $1.5-2$ & $2-2.5$ & $2.5-3$ & $3-3.5$ & $3.5-4$ & $4-5$ & $5-6$ & $6-7$ & $7-8$ & $8-9$ & $9-10$ & Total & $\%$ \\
\hline \multicolumn{17}{|l|}{ Porcellaneous } \\
\hline Biloculinella spp. & 1 & & 2 & & & & & & & & & & & & 3 & 0.62 \\
\hline Miliolinella subrotunda & & 2 & & & & & & & & & & & & & 2 & 0.41 \\
\hline Pyrgo elongata & & 3 & 2 & 3 & 1 & & & & & & & & & & 9 & 1.86 \\
\hline Pyrgoella sphaera & & 1 & & & & & & & & & & & & & 1 & 0.21 \\
\hline \multicolumn{17}{|l|}{ Fossilizing agglutinates } \\
\hline Bigenerina nodosaria & 36 & 38 & 14 & 5 & 2 & & & & & 1 & & & & & 96 & 19.79 \\
\hline Clavulina cylindrica & 1 & 5 & 4 & 6 & 1 & & 1 & & & & & & & & 18 & 3.71 \\
\hline Sigmoilopsis schlumbergeri & & 1 & & & & & & & & & & & & & 1 & 0.21 \\
\hline Siphotextularia concava & 2 & 2 & 2 & & & & & 1 & & 1 & & 1 & & & 9 & 1.86 \\
\hline Textularia agglutinans & 5 & 11 & 1 & 1 & 1 & & & 1 & & & & & & 1 & 21 & 4.33 \\
\hline \multicolumn{17}{|l|}{ Non-fossilizing agglutinates } \\
\hline Haplophragmoides spp. & & & 1 & & & & & & & & & & & & 1 & 0.21 \\
\hline Psammosphaera spp. & 3 & 1 & & & & & & & & & & & & & 4 & 0.82 \\
\hline Pseudoclavulina crustata & 1 & & & & & & & & & & & & & & 1 & 0.21 \\
\hline Recurvoides spp. & & 5 & 3 & & 1 & & & & & & & & & & 9 & 1.86 \\
\hline Reophax dentaliniformis & & & 1 & & 1 & & & & & & & & & & 2 & 0.41 \\
\hline Reophax spiculifer & & 1 & 3 & & & & & & & & & & & & 4 & 0.82 \\
\hline Total living specimens & 74 & 100 & 67 & 43 & 43 & 20 & 19 & 6 & 50 & 38 & 17 & 5 & 1 & 2 & 485 & 100 \\
\hline Species number & 19 & 26 & 19 & 16 & 16 & 9 & 11 & 5 & 6 & 6 & 4 & 4 & 1 & 2 & & \\
\hline
\end{tabular}

Appendix B. Census data (non-standardized) of live benthic foraminifera at station FP12. All numbers are based on the study of one interface core with a $\sim 71 \mathrm{~cm}^{2}$ surface area

Données non standardisées des foraminifères vivants à la station FP12 basées sur l'étude d'une carotte de $\sim 71 \mathrm{~cm}^{2}$ de surface

\begin{tabular}{|c|c|c|c|c|c|c|c|c|c|c|c|c|c|c|c|}
\hline \multicolumn{16}{|l|}{ Station FP12 } \\
\hline Sediment level (cm) & $0-0.5$ & $0.5-1.5$ & $1.5-2$ & $2-2.5$ & $2.5-3$ & $3-3.5$ & $3.5-4$ & $4-5$ & $5-6$ & $6-7$ & $7-8$ & $8-9$ & $9-10$ & Total & $\%$ \\
\hline \multicolumn{16}{|l|}{ Perforates } \\
\hline Amphicoryna scalaris & 1 & & & & & & & & & & & & & 1 & 0.71 \\
\hline Cibicidoides pachydermus & & & & 1 & & & & & & & & & & 1 & 0.71 \\
\hline Cibicidoides ungerianus & 2 & & & & & & & & & & & & & 2 & 1.43 \\
\hline Dentalina spp. & & 1 & & & & & & & & & & & & 1 & 0.71 \\
\hline Glandulina spp. & & & & & 1 & & & & & & & & & 1 & 0.71 \\
\hline Globobulimina spp. & & & 1 & & & & & 1 & & & & & & 2 & 1.43 \\
\hline Gyroidina orbicularis & & 2 & & & & & & & & & & & & 2 & 1.43 \\
\hline Hoeglundina elegans & & 1 & & & & & & & & & & & & 1 & 0.71 \\
\hline Hyalinea balthica & & 1 & & & & & & & & & & & & 1 & 0.71 \\
\hline Lenticulina gibba & 2 & & & & & & & & & & & & & 2 & 1.43 \\
\hline Lenticulina vortex & 1 & & & & & & & & & & & & & 1 & 0.71 \\
\hline Marginula obesa & 1 & & & & & & & & & & & & & 1 & 0.71 \\
\hline Melonis barleeanus & & 6 & 1 & & & & & & & & & & & 7 & 5.00 \\
\hline Nuttallides umboniferus & & 1 & & & & & & & & & & & & 1 & 0.71 \\
\hline Pullenia quinqueloba & & & 1 & & & & & & & & & & & 1 & 0.71 \\
\hline Siphogenerina columellaris & & & 1 & & & & & & & & & & & 1 & 0.71 \\
\hline Uvigerina mediterranea & 46 & 15 & 1 & 3 & & & & & & 1 & 1 & & & 67 & 47.86 \\
\hline Uvigerina peregrina & & 2 & & & & & & & & & & & & 2 & 1.43 \\
\hline \multicolumn{16}{|l|}{ Porcellaneous } \\
\hline Cornuspira spp. & 1 & & & & & & & & & & & & & 1 & 0.71 \\
\hline Cruciloculina spp. & 1 & & & & & & & & & & & & & 1 & 0.71 \\
\hline Pyrgo depressa & 3 & 1 & & & & & & & & & & & & 4 & 2.86 \\
\hline Pyrgo lucernula & 3 & 2 & & & & & & & & & & & & 5 & 3.57 \\
\hline Pyrgo spp. & 1 & & & & & & & & & & & & & 1 & 0.71 \\
\hline \multicolumn{16}{|l|}{ Fossilizing agglutinates } \\
\hline Sigmoilopsis schlumbergeri & & 2 & & & 4 & & & & & & & & & 6 & 4.29 \\
\hline
\end{tabular}


Appendix B (Continued)

\begin{tabular}{|c|c|c|c|c|c|c|c|c|c|c|c|c|c|c|c|}
\hline \multicolumn{16}{|l|}{ Station FP12 } \\
\hline Sediment level $(\mathrm{cm})$ & $0-0.5$ & $0.5-1.5$ & $1.5-2$ & $2-2.5$ & $2.5-3$ & $3-3.5$ & $3.5-4$ & $4-5$ & $5-6$ & $6-7$ & $7-8$ & $8-9$ & $9-10$ & Total & $\%$ \\
\hline \multicolumn{16}{|l|}{ Non-fossilizing agglutinates } \\
\hline Ammolagena spp. & & 1 & & & & & & & & & & & & 1 & 0.71 \\
\hline Cribrostomoides spp. & 4 & 6 & & & & & & & & & & & & 10 & 7.14 \\
\hline Glomospira charoides & 3 & & & & & & & & & & & & & 3 & 2.14 \\
\hline Psammosphaera spp. & 9 & & & & & & & & & & & & & 9 & 6.43 \\
\hline Recurvoides spp. & 1 & 1 & & & & & & & & & & & & 2 & 1.43 \\
\hline Tritaxis challengeri & & & 2 & & & & & & & & & & & 2 & 1.43 \\
\hline Total living specimens & 79 & 42 & 7 & 4 & 5 & & & 1 & & 1 & 1 & & & 140 & 1 \\
\hline Species number & 15 & 14 & 6 & 2 & 2 & & & 1 & & 1 & 1 & & & & \\
\hline
\end{tabular}

Appendix C. Census data (non-standardized) of live benthic foraminifera at station FP11. All numbers are totals for 2 investigated cores, each with a $\sim 71 \mathrm{~cm}^{2}$ surface area

Données non standardisées des foraminifères vivants à la station FP11. Les nombres sont les totaux basés sur l'étude de 2 carottes de $\sim 71 \mathrm{~cm}^{2}$ de surface chacune

\begin{tabular}{|c|c|c|c|c|c|c|c|c|c|c|c|c|c|c|c|c|}
\hline \multicolumn{17}{|l|}{ Station FP11 } \\
\hline Sediment level $(\mathrm{cm})$ & $0-0.5$ & $0.5-1$ & $1-1.5$ & $1.5-2$ & $2-2.5$ & $2.5-3$ & $3-3.5$ & $3.5-4$ & $4-5$ & $5-6$ & $6-7$ & $7-8$ & $8-9$ & $9-10$ & Total & $\%$ \\
\hline \multicolumn{17}{|l|}{ Perforates } \\
\hline Bulimina inflata & 3 & 4 & & & & 1 & 1 & & & & & & & 1 & 10 & 3.1 \\
\hline Cibicidoides kullenbergi & 36 & 42 & 2 & & & 1 & & & & & & & & & 81 & 25.4 \\
\hline Cibicidoides robertsonianus & 1 & 8 & 2 & & & & & & & & & & & & 11 & 3.4 \\
\hline Cyclogyra involvens & & 1 & & & 1 & & & & & & & & & & 2 & 0.6 \\
\hline Fissurina sp. & & & & & 1 & & 1 & & & & & & & & 2 & 0.6 \\
\hline Gavelinopsis transluscens & 10 & 2 & & & & 2 & & & & & 1 & & 1 & & 16 & 5,0 \\
\hline Globobulimina spp. & & & & & & & & & & & 2 & 1 & & & 3 & 0.9 \\
\hline Gyroidina orbicularis & 2 & 6 & & & 3 & 4 & & & 1 & & 1 & & & & 17 & 5.3 \\
\hline Hoeglundina elegans & 53 & 11 & & & & 1 & 3 & & & & 1 & 1 & & & 70 & 21.9 \\
\hline Melonis barleeanus & & & & & 1 & 1 & & 1 & 2 & & 1 & & & & 6 & 1.9 \\
\hline Nonion sp. & & 1 & & & & & & & & & & & & & 1 & 0.3 \\
\hline Oridorsalis umbonatus & 2 & & & & & 1 & & & & & & & & & 3 & 0.9 \\
\hline Pullenia bulloides & & & & & & & & & 1 & & & & & & 1 & 0.3 \\
\hline Pullenia quinqueloba & 1 & & 1 & 1 & & & & & & 4 & & & & & 7 & 2.2 \\
\hline Uvigerina peregrina & 10 & 11 & & 1 & & & 1 & & & & & & 1 & & 24 & 7.5 \\
\hline \multicolumn{17}{|l|}{ Porcellaneous } \\
\hline Miliolinella spp. & 3 & & & & & & 1 & & & & & & & & 4 & 1.3 \\
\hline Pyrgo elongata & 7 & 4 & 2 & 1 & & & 1 & & 1 & & & & & & 16 & 5.0 \\
\hline Pyrgo subsphaerica & 5 & 1 & & & & & & & & & & & & & 6 & 1.9 \\
\hline Quinqueloculina sp. 1 & 2 & & & & & & & & & & & & & & 2 & 0.6 \\
\hline Spiroloculina sp. & 1 & & & & & & & & & & & & & & 1 & 0.3 \\
\hline \multicolumn{17}{|l|}{ Fossilizing agglutinates } \\
\hline Egerella bradyi & 1 & 5 & & & & & & 1 & & & & & & & 7 & 2.2 \\
\hline Textularia sp. & 1 & & & & & & & & & & & & & & 1 & 0.3 \\
\hline \multicolumn{17}{|l|}{ Non-fossilizing agglutinates } \\
\hline Cribrostomoides spp. & 1 & 4 & 2 & 2 & & 1 & & & & 2 & & 1 & & & 13 & 4.1 \\
\hline Glomospira cordialis & & & 1 & & & & & & & & & & & & 1 & 0.3 \\
\hline Pseudonosaria sp. & 1 & & & & & & & & & & & & & & 1 & 0.3 \\
\hline Reophax dentaliniformis & & 2 & 1 & & & & & & & & & & & & 3 & 0.9 \\
\hline Trochammina spp. & & & 2 & & & & & & & & 8 & & & & 10 & 3.1 \\
\hline Total living specimens & 140 & 102 & 13 & 5 & 6 & 12 & 8 & 2 & 5 & 6 & 14 & 3 & 2 & 1 & 319 & 100 \\
\hline Species number & 18 & 14 & 8 & 4 & 4 & 8 & 6 & 2 & 4 & 2 & 6 & 3 & 2 & 1 & & \\
\hline
\end{tabular}


Appendix D. Census data (non-standardized) of live benthic foraminifera at station FP1. All numbers are totals for 6 investigated cores, each with a $\sim 31 \mathrm{~cm}^{2}$ surface area

Données non standardisées des foraminifères vivants à la station FP1. Les nombres sont les totaux basés sur l'étude de 6 carottes de $\sim 31 \mathrm{~cm}^{2}$ de surface chacune

\begin{tabular}{|c|c|c|c|c|c|c|c|c|c|c|c|c|c|c|c|c|}
\hline \multicolumn{17}{|l|}{ Station FP1 } \\
\hline Sediment level (cm) & $0-0.5$ & $0.5-1$ & $1-1.5$ & $1.5-2$ & $2-2.5$ & $2.5-3$ & $3-3.5$ & $3.5-4$ & $4-5$ & $5-6$ & $6-7$ & $7-8$ & $8-9$ & $9-10$ & Total & $\%$ \\
\hline \multicolumn{17}{|l|}{ Perforates } \\
\hline Bolivina sp. & 1 & & & & & & & & & & & & & & 1 & 0.6 \\
\hline Bulimina alazanensis & 13 & 4 & 2 & & & & & & & & & & & & 19 & 11.3 \\
\hline Bulimina inflata & 10 & & & & & & & & & & & & & & 10 & 6.0 \\
\hline Cassidulina crassa & 1 & & & & & & & & & & & & & & 1 & 0.6 \\
\hline Cibicides wuellerstorfi & 2 & & & & & & & & & & & & & & 2 & 1.2 \\
\hline Cibicidoides kullenbergi & 2 & & & 1 & & & & & & & & & & & 3 & 1.8 \\
\hline Cibicidoides ungerianus & 6 & & & & & & & & & & & & & & 6 & 3.6 \\
\hline Gavelinopsis transluscens & 8 & & & & & & & & & & & & & & 8 & 4.8 \\
\hline Gyroidina orbicularis & 2 & & 1 & & & & & & & & & & & & 3 & 1.8 \\
\hline Gyroidina soldanii & & 1 & 1 & & & & & & & & & & & & 2 & 1.2 \\
\hline Hoeglundina elegans & 9 & & & & & & & & & & & & & & 9 & 5.4 \\
\hline Lagena hispidula & & & 2 & 1 & & & & & & & & & & & 3 & 1.8 \\
\hline Melonis zaandamae & & & 2 & & & & & & & & & & & & 2 & 1.2 \\
\hline Nonionella sp. & 1 & & & & & & & & & & & & & & 1 & 0.6 \\
\hline Nutallides umboniferus & 3 & & & & & & & & & & & & & & 3 & 1.8 \\
\hline Pullenia bulloides & & & 1 & & & & & & & & & & & & 1 & 0.6 \\
\hline Pullenia quinqueloba & 1 & 3 & 2 & & & & & & & & & & & & 6 & 3.6 \\
\hline Robertinoides spp. & 1 & & & & & & & & & & & & & & 1 & 0.6 \\
\hline Spirillina decorata & 1 & & & & & & & & & & & & & & 1 & 0.6 \\
\hline Trifarina sp. & & 1 & & & & & & & & & & & & & 1 & 0.6 \\
\hline Uvigerina peregrina & 8 & & 1 & & & & & & & & & & & & 9 & 5.4 \\
\hline Indet. & 6 & & & & & & & & & & & & & & 6 & 3.6 \\
\hline \multicolumn{17}{|l|}{ Porcellaneous } \\
\hline Biloculinella spp. & 4 & 1 & & & & & & & & & & & & & 5 & 3,0 \\
\hline Miliolinella spp. & 2 & & & & & & & & & & & & & & 2 & 1.2 \\
\hline Pyrgo depressa & 2 & & & & & & & & & & & & & & 2 & 1.2 \\
\hline Pyrgo murrhina & & 1 & & & & & & & & & & & & & 1 & 0.6 \\
\hline Pyrgoella sphaera & 1 & 1 & 1 & & & & & & & & & & & & 3 & 1.8 \\
\hline \multicolumn{17}{|l|}{ Fossilizing agglutinates } \\
\hline Egerella bradyi & 3 & 2 & 1 & & & & & & & & & & & & 6 & 3.6 \\
\hline Textularia conica & 1 & & & & & & & & & & & & & & 1 & 0.6 \\
\hline Textularia sp. & 1 & & & & & & & & & & & & & & 1 & 0.6 \\
\hline \multicolumn{17}{|l|}{ Non-fossilizing agglutinates } \\
\hline Ammobaculites agglutinans & 10 & & 1 & & & & & & & & & & & & 11 & 6.5 \\
\hline Ammodiscus spp. & 2 & & 1 & & & & & & & & & & & & 3 & 1.8 \\
\hline Cribrostomoides spp. & 2 & 4 & 1 & 1 & 1 & & & & & & & & & & 9 & 5.4 \\
\hline Haplophragmoides spp. & 2 & & & & & & & & & & & & & & 2 & 1.2 \\
\hline Recurvoides sp. & & & 1 & & & & & & & & & & & & 1 & 0.6 \\
\hline Reophax bilocularis & 1 & & & & & & & & & & & & & & 1 & 0.6 \\
\hline Reophax dentaliniformis & 2 & 2 & 5 & & & & & & & & & & & & 9 & 5.4 \\
\hline Reophax guttiferus & 6 & 1 & & & & & & & & & & & & & 7 & 4.2 \\
\hline Reophax scorpiurus & 3 & & & & & & & & & & & & & & 3 & 1.8 \\
\hline Scuttuloris sp. & 1 & & & & & & & & & & & & & & 1 & 0.6 \\
\hline Spiroplectammina wrightii & 1 & & & & & & & & & & & & & & 1 & 0.6 \\
\hline Technitella melo & 1 & & & & & & & & & & & & & & 1 & 0.6 \\
\hline Total living specimens & 120 & 21 & 23 & 3 & 1 & & & & & & & & & & 168 & 100 \\
\hline Species number & 35 & 11 & 15 & 3 & 1 & & & & & & & & & & & \\
\hline
\end{tabular}


Appendix E. Census data (non-standardized) of live benthic foraminifera at station FP2. All numbers are totals for 6 investigated cores, each with a $\sim 31 \mathrm{~cm}^{2}$ surface area

Données non standardisées des foraminifères vivants à la station FP2. Les nombres sont les totaux basés sur l'étude de 6 carottes de $\sim 31 \mathrm{~cm}^{2}$ de surface chacune

\begin{tabular}{|c|c|c|c|c|c|c|c|c|c|c|c|c|c|c|c|c|}
\hline \multicolumn{17}{|l|}{ Station FP2 } \\
\hline Sediment level $(\mathrm{cm})$ & $0-0.5$ & $0.5-1$ & $1-1.5$ & $1.5-2$ & $2-2.5$ & $2.5-3$ & $3-3.5$ & $3.5-4$ & $4-5$ & $5-6$ & $6-7$ & $7-8$ & $8-9$ & $9-10$ & Total & $\%$ \\
\hline \multicolumn{17}{|l|}{ Perforates } \\
\hline Cibicides wuellerstorfi & 4 & & & & & & & & & & & & & & 4 & 3.8 \\
\hline Epistominella exigua & 2 & 1 & 1 & & & & & & & & & & & & 4 & 3.8 \\
\hline Gyroidina orbicularis & & & 1 & & & & & & & & & & & & 1 & 1.0 \\
\hline Melonis pompilioides & 6 & 1 & & & & & & & & & & & & & 7 & 6.7 \\
\hline Melonis zaandamae & & 1 & & & & & & & & & & & & & 1 & 1.0 \\
\hline Nutallides umboniferus & 10 & 7 & 1 & & & & & & & & & & & & 18 & 17.3 \\
\hline Oridorsalis umbonatus & 1 & 2 & 1 & & & & & & & & & & & & 4 & 3.8 \\
\hline \multicolumn{17}{|l|}{ Porcellaneous } \\
\hline Biloculinella spp. & 2 & 2 & & & & & & & & & & & & & 4 & 3.8 \\
\hline Pyrgo subsphaerica & 1 & 1 & 1 & & & & & & & & & & & & 3 & 2.9 \\
\hline Pyrgoella sphaera & & 1 & & & & & & & & & & & & & 1 & 1.0 \\
\hline Quinqueloculina sp. 1 & 5 & 3 & & 1 & & & & & & & & & & & 9 & 8.7 \\
\hline \multicolumn{17}{|l|}{ Fossilizing agglutinates } \\
\hline Eggerella bradyi & 20 & 7 & 1 & 1 & & & & & & & & & & & 29 & 27.9 \\
\hline \multicolumn{17}{|l|}{ Non-fossilizing agglutinates } \\
\hline Ammobaculites agglutinans & 2 & 1 & & & & & & & & & & & & & 3 & 2.9 \\
\hline Cribrostomoides spp. & 2 & 1 & & & & & & & & & & & & & 3 & 2.9 \\
\hline Eggerella spp. & 1 & & & & & & & & & & & & & & 1 & 1.0 \\
\hline Haplophragmoides spp. & 2 & & & & & & & & & & & & & & 2 & 1.9 \\
\hline Reophax dentaliniformis & & 1 & & 1 & & & & & & & & & & & 2 & 1.9 \\
\hline Reophax piluliferis & 1 & & & & & & & & & & & & & & 1 & 1.0 \\
\hline Reophax scorpiurus & & 1 & & & & & & & & & & & & & 1 & 1.0 \\
\hline Robertinoides bradyi & & & 1 & 1 & & & & & & & & & & & 2 & 1.9 \\
\hline Saccammina spp. & & 1 & & & & & & & & & & & & & 1 & 1.0 \\
\hline Scuttuloris sp. & 1 & 1 & 1 & & & & & & & & & & & & 3 & 2.9 \\
\hline Total living specimens & 60 & 32 & 8 & 4 & & & & & & & & & & & 104 & 100 \\
\hline Species number & 15 & 16 & 8 & 4 & & & & & & & & & & & & \\
\hline
\end{tabular}

Appendix F. Taxonomic reference list. For all taxa determined at a species level, a modern reference is given, in which the species is correctly figured

Liste des références taxonomiques. Pour chaque taxon déterminé au niveau spécifique, une référence récente, dans laquelle l'espèce est correctement figurée, est donnée

\begin{tabular}{|c|c|}
\hline Species & References \\
\hline Ammobaculites agglutinans (d'Orbigny, 1846) & Hess (1998), pl. 4, fig. 4 \\
\hline Amphicoryna scalaris (Batsch, 1791) & Jones (1994), pl. 63, figs. 28-31 \\
\hline Bigenerina nodosaria (d'Orbigny, 1826) & Jones (1994), pl. 44, figs. 19-24 \\
\hline Bolivina alata (Seguenza, 1862) & Wright (1978), pl. 1, fig. 13 \\
\hline Bolivina striatula (Cushman, 1922) & Cimerman and Langer (1991), pl. 62, figs. 6-9 \\
\hline Bolivina subaenariensis (Cushman, 1922) & Phleger et al. (1953), pl. 7, figs. 24, 25 \\
\hline Bolivinata quadrilatera (Schwager, 1866) & Jones (1994), pl. 42, figs. 8-12 \\
\hline Bulimina aculeata (d'Orbigny, 1826) & Jones (1994), pl. 51, figs. 7-9 \\
\hline Bulimina alazanensis (Cushman, 1927) & Hess (1998), pl. 10, fig. 10 \\
\hline Bulimina costata (d'Orbigny, 1852) & Van Leeuwen (1989), pl. 8, figs. 2, 3 \\
\hline Bulimina inflata (Seguenza, 1862) & Van Leeuwen (1989), pl. 8, fig. 4 \\
\hline Bulimina marginata (d’Orbigny, 1826) & Hess (1998), pl. 10, fig. 7 \\
\hline Cancris auriculus (Fichtel and Moll, 1942) & Jones (1994), pl. 106, fig. 4 \\
\hline Cassidulina carinata (Silvestri, 1896) & Phleger et al. (1953), pl. 9, figs. 32-37 \\
\hline Cassidulina crassa (d’Orbigny, 1839) & Jones (1994), pl. 54, fig. 4 \\
\hline Chilostomella oolina (Schwager, 1878) & Jones (1994), pl. 55, figs. 12-14 \\
\hline
\end{tabular}


Appendix F (Continued)

\begin{tabular}{|c|c|}
\hline Species & References \\
\hline Cibicides wuellerstorfi (Schwager, 1866) & Van Leeuwen (1989), pl. 10, figs. 1-9 \\
\hline Cibicidoides kullenbergi (Parker, 1953) & Wright (1978), pl. 4, figs. 5-7 \\
\hline Cibicidoides pachydermus (Rzehac, 1886) & Jones (1994), pl. 94, fig. 9 \\
\hline Cibicidoides robertsonianus (Brady, 1881) & Van Leeuwen (1989), pl. 9, figs. 1-3 \\
\hline Cibicidoides ungerianus (d'Orbigny, 1846) & Marks (1951), pl. 8, figs. 2a, b \\
\hline Clavulina cylindrica (Cushman, 1922) & Jones (1994), pl. 44, figs. 19-24 \\
\hline Cyclogyra involvens (Reuss, 1849) & Jones (1994), pl. 11, figs. 1-3 \\
\hline Dentalina bradyensis (Dervieux, 1894) & Jones (1994), pl. 62, figs. 19, 20 \\
\hline Dentalina subemaciata (Parr, 1950) & Jones (1994), pl. 62, figs. 25, 26 \\
\hline Eggerella bradyi (Cushman, 1911) & Jones (1994), pl. 47, figs. 4-7 \\
\hline Epistominella exigua (Brady, 1884) & Jones (1994), pl. 103, figs. 13, 14 \\
\hline Gavelinopsis translucens (Phleger and Parker, 1951) & Schiebel (1992), pl. 4, fig. 5 \\
\hline Glomospira charoides (Jones and Parker, 1860) & Phleger et al. (1953), pl. 5, fig. 1 \\
\hline Glomospira cordialis (Jones and Parker, 1860) & Phleger et al. (1953), pl. 5, fig. 2 \\
\hline Gyroidina orbicularis (d’Orbigny, 1826) & Jorissen (1987), pl. 1, fig. 13 \\
\hline Gyroidina soldanii (d’Orbigny, 1846) & Longinelli (1956), pl. 14, fig. 16 \\
\hline Hanzawaia boueana (d'Orbigny, 1846) & Jorissen (1987), pl. 3, fig. 10 \\
\hline Hoeglundina elegans (d'Orbigny, 1826) & Phleger et al. (1953), pl. 9, figs. 24, 25 \\
\hline Hyalinea balthica (Schroeter, 1783) & Jones (1994), pl. 112, figs. 1, 2 \\
\hline Lagena hispidula (Cushman, 1913) & Jones (1994), pl. 56, figs. 10, 11 \\
\hline Lagenammina difflugiformis (Brady, 1879) & Mackensen et al. (1990), pl. 6, fig. 9 \\
\hline Lenticulina gibba (d’Orbigny, 1839) & Jones (1994), pl. 69, figs. 8, 9 \\
\hline Lenticulina peregrina (Schwager, 1866) & Cushman and McCulloch (1950), pl. 39, fig. 5 \\
\hline Lenticulina vortex (Fitchell and Moll, 1798) & Jones (1994), pl. 69, figs. 14-16 \\
\hline Marginula obesa (Cushman, 1923) & Jones (1994), pl. 65, figs. 5, 6 \\
\hline Melonis barleeanus (Williamson, 1858) & Van Leeuwen (1989), pl. 13, figs. 1, 2 \\
\hline Melonis pompilioides (Fichtel and Moll, 1798) & Van Marle (1991), pl. 20, figs. 4-6 \\
\hline Melonis zaandamae (Van Voorthuysen, 1952) & Schmiedl et al. (1997), pl. 2, figs. 12, 13 \\
\hline Miliolinella subrotunda (Montagu, 1803) & Jones (1994), pl. 4, fig. 3 \\
\hline Nonion fabum (Fichtel and Moll, 1798) & Loeblich and Tappan (1988), pl. 690, figs. 1-7 \\
\hline Nonionella turgida (Williamson, 1858) & Jones (1994), pl. 109, figs. 17-19 \\
\hline Nuttallides umboniferus (Cushman, 1933) & Van Leeuwen (1989), pl. 15, figs. 11-13; pl. 16, figs. 1-7 \\
\hline Oridorsalis umbonatus (Reuss, 1851) & Van Leeuwen (1989), pl. 17, figs. 1-13 \\
\hline Pseudoclavulina crustata (Cushman, 1936) & Jorissen (1987), pl. 1, fig. 1 \\
\hline Pullenia bulloides (d'Orbigny, 1826) & Phleger et al. (1953), pl. 10, fig. 19 \\
\hline Pullenia quinqueloba (Reuss, 1851) & Marks (1951), pl. 7, fig. 19 \\
\hline Pyrgo depressa (d'Orbigny, 1826) & Jones (1994), pl. 2, figs. 12, 16, 17 \\
\hline Pyrgo elongata (d'Orbigny, 1826) & Jones (1994), pl. 2, fig. 9 \\
\hline Pyrgo lucernula (Schwager, 1891) & Jones (1994), pl. 2, figs. 5, 6 \\
\hline Pyrgo murrhina (Schwager, 1866) & Hess (1998), pl. 9, fig. 1 \\
\hline Pyrgo subsphaerica (d’Orbigny, 1839) & Cushman (1929), pl. 18, figs. 1, 2 \\
\hline Pyrgoella sphaera (d'Orbigny, 1839) & Jones (1994), pl. 2, fig. 4 \\
\hline Reophax bilocularis (Flint, 1899) & Schmiedl et al. (1997), pl. 1, figs. 3, 4 \\
\hline Reophax dentaliniformis (Brady, 1881) & Jones (1994), pl. 30, figs. 21, 22 \\
\hline Reophax guttiferus (Brady, 1881) & Jones (1994), pl. 30, figs. 10-15 \\
\hline Reophax scorpiurus (Montfort, 1808) & Loeblich and Tappan (1988), pl. 44, figs. 1-3 \\
\hline Reophax spiculifer (Brady, 1879) & Jones (1994), pl. 31, figs. 16, 17 \\
\hline Reophax piluliferis (Brady, 1884) & Jones (1994), pl. 30, figs. 18-20 \\
\hline Robertinoides bradyi (Cushman and Parker, 1936) & Jones (1994), pl. 50, fig. 18 \\
\hline Sigmoilopsis schlumbergeri (Silvestri, 1904) & Jones (1994), pl. 8, figs. 1-4 \\
\hline Siphogenerina columellaris (Brady, 1881) & Jones (1994), pl. 75, figs. 15-17 \\
\hline Siphotextularia concava (Karrer, 1868) & Jones (1994), pl. 42, figs. 13, 14 \\
\hline Sphaeroidina bulloides (d'Orbigny, 1826) & Longinelli (1956), pl. 10, fig. 1 \\
\hline Spirillina decorata (Brady, 1884) & Jones (1994), pl. 85, figs. 22-25 \\
\hline Spiroplectammina wrightii (Silvestri, 1903) & Jones (1994), pl. 42, figs. 17, 18 \\
\hline Technitella melo (Norman, 1978) & Jones (1994), pl. 25, fig. 7 \\
\hline Textularia agglutinans (d'Orbigny, 1839) & Jones (1994), pl. 43, figs. 1-3 \\
\hline Textularia conica (d'Orbigny, 1839) & Le Calvez (1977), pl. 18, figs. 1, 2 \\
\hline Trifarina bradyi (Cushman, 1923) & Jones (1994), pl. 67, figs. 1-3 \\
\hline Tritaxis challengeri (Hedley, Hurdle and Burdett, 1964) & Jones (1994), pl. 41, fig. 3 \\
\hline Uvigerina elongatastriata (Colom, 1952) & Van der Zwaan et al. (1986), pl. 6, figs. 1-8 \\
\hline Uvigerina mediterranea (Hofker, 1932) & Van der Zwaan et al. (1986), pl. 5, figs. 1-7 \\
\hline Uvigerina peregrina (Cushman, 1923) & Van Der Zwaan et al. (1986), pl. 1, figs. 1-6 \\
\hline Valvulineria bradyana (Fornasini, 1900) & Jorissen (1987), pl. 4, figs. 1, 2 \\
\hline
\end{tabular}




\section{References}

Altenbach, A.V., 1985. Die Biomasse der benthischen Foraminiferen. Auswertungen von, Meteor"-Expedition im östlichen Nordatlantik. Ph.D. Thesis, Kiel University, Germany.

Altenbach, A.V., Pflaumann, U., Schiebel, R., Thies, A., Timm, S., Trauth, M., 1999. Scaling percentages and distributional patterns of benthic foraminifera with flux rates of organic carbon. Journal of Foraminiferal Research 29, 173-185.

Altenbach, A.V., Sarthein, M., 1989. Productivity record in benthic foraminifera. In: Berger, W.H., Smetacek, V.S., Wefer, G. (Eds.), Productivity of the ocean: present and past. John Wiley, Chichester, pp. 255-269.

Barnett, P.R.O., Watson, J., Connelly, D., 1984. A multiple corer for taking virtually undisturbed sample from shelf, bathyal and abyssal sediments. Oceanologica Acta 7, 399-408.

Berger, W.H., Wefer, G., 1990. Export productivity: seasonality and intermittency, and paleoceanographic implications. Palaeogeography, Palaeoclimatology, Palaeoecology 89, 245-254.

Bernhard, J.M., 1988. Postmortem vital staining in benthic foraminifera: Duration and importance in population and distributional studies. Journal of Foraminiferal Research 18, 143-146.

Bernhard, J.M., 1992. Benthic foraminiferal distribution and biomass related to porewater oxygen content: central California continental slope and rise. Deep-Sea Research 39, 585-605

Bernhard, J.M., Ostermann, D.R., Williams, D.S., Blanks, J.K., 2006. Comparison of two methods to identify live benthic foraminifera: a test between Rose Bengal and CellTracker Green with implications for stable isotope paleoreconstructions. Paleoceanography 21, PA4210, doi:10.1029/2006PA001290.

Bernhard, J.M., Reimers, C.E., 1991. Benthic foraminiferal population fluctuations related to anoxia: Santa Barbara Basin. Biogeochemistry 15, 127-149.

Bernhard, J.M., Sen Gupta, B.K., Borne, P.F., 1997. Benthic foraminiferal proxy to estimate dysoxic bottom-water oxygen concentrations; Santa Barbara basin, U.S. Pacific continental margin. Journal of Foraminiferal Research 27, 301-310.

Buzas, M., Culver, S.J., Jorissen, F.J., 1993. A statistical evaluation of the microhabitats of living (stained) infaunal benthic foraminifera. Marine Micropaleontology 20, 3-4.

Caralp, H.M., 1987. Deep-sea circulation in the northeastern Atlantic over the past 30,000 years: the benthic foraminiferal record. Oceanologica Acta 10, $27-40$.

Caralp, H.M., 1989. Abundance of Bulimina exilis and Melonis barleeanum: relationship to the quality of marine organic matter. Geo-Marine Letters 9, 37-43.

Corliss, B.H., 1985. Microhabitats of benthic foraminifera within deep-sea sediments. Nature 314, 435-438.

Corliss, B.H., 1991. Morphology and microhabitat preferences of benthic foraminifera from the northwest Atlantic Ocean. Marine Micropaleontology 17, 195-236.

Corliss, B.H., Chen, C., 1988. Morphotype patterns of Norwegian Sea deep-sea benthic foraminifera and ecological implications. Geology 16, 716-719.

Corliss, B.H., Emerson, S., 1990. Distribution of Rose Bengal stained deep-sea benthic foraminifera from the Nova Scotia continental margin and Gulf of Maine. Deep-Sea Research 37, 381-400.

De Rijk, S., Jorissen, F.J., Rohling, E.J., Troelstra, S.R., 2000. Organic flux control on bathymetric zonation of Mediterranean benthic foraminifera. Marine Micropaleontology 40, 151-166.

Douglas, R.G., 1981. Paleoecology of continental margin basins: a modern case history from the borderland of Southern California. In: Douglas, R.G. (Ed.), Depositional systems of active continental margin basins. Society of Economic Paleontologists and Mineralogists (SEPM), Bakersfield, California, pp. 121-156.

Fariduddin, M., Loubere, P., 1997. The surface ocean productivity response of deeper water benthic foraminifera in the Atlantic Ocean. Marine Micropaleontology 32, 289-310.

Fontanier, C., Jorissen, F.J., Anschutz, P., Chaillou, G., 2006. Seasonal variability of benthic foraminiferal faunas at $1000 \mathrm{~m}$ depth in the Bay of Biscay. Journal of Foraminiferal Research 36, 61-76.
Fontanier, C., Jorissen, F.J., Chaillou, G., David, C., Anschutz, P., Lafon, V., 2003. Seasonal and interannual variability of benthic foraminiferal faunas at $550 \mathrm{~m}$ depth in the Bay of Biscay. Deep-Sea Research I 50, 457-494.

Fontanier, C., Jorissen, F.J., Licari, L., Alexandre, A., Anschutz, P., Carbonel, P., 2002. Live benthic foraminiferal faunas from the Bay of Biscay: faunal density, composition, and microhabitats. Deep-Sea Research I 49, 751-785.

Gooday, A.J., 1988. A response by benthic foraminifera to the deposition of phytodetritus in the deep-sea. Nature 332, 70-73.

Gooday, A.J., 1993. Deep-sea benthic foraminiferal species which exploit phytodetritus: Characteristic features and controls on distribution. Marine Micropaleontology 22, 187-205.

Gooday, A.J., 2003. Benthic foraminifera (Protista) as tools in deep-water palaeoceanography: Environmental influences on faunal characteristics. In: Advances in Marine Biology. Academic Press, pp. 1-90.

Gooday, A.J., Lambshead, P.J.D., 1989. Influence of seasonally deposited phytodetritus on benthic foraminiferal populations in the bathyal northeast Atlantic: the species response. Marine Ecology-Progress Series 58, 53-97.

Gooday, A.J., Levin, L.A., Linke, P., Heeger, T., 1992. The role of benthic foraminifera in deep-sea food webs and carbon cycling. In: Rowe, G.T., Patiente, V. (Eds.), Deep-sea food chains and the Global Carbon Cycle. Kluwer Academic Publishers, Dordrecht, pp. 63-91.

Harloff, J., Mackensen, A., 1997. Recent benthic foraminiferal associations and ecology of the Scotia Sea and Argentine Basin. Marine Micropaleontology 31, 1-29.

Helder, W., Bakker, J.F., 1985. Shipboard comparison of micro- and mini electrodes for measuring oxygen in marine sediments. Limnology and Oceanography 30, 1106-1109.

Herguera, J.C., 1992. Deep-sea foraminifera and biogenic opal: Glacial to postglacial productivity changes in the western Pacific. Marine Micropaleontology 19, 79-98.

Heussner, S., Durrieu de Madron, X., Radakovitch, O., Beaufort, L., Biscaye, P.E., Carbonne, J., et al., 1999. Spatial and temporal patterns of downward particle fluxes on the continental slope of the Bay of Biscay (northeastern Atlantic). Deep-Sea Research II 46, 2101-2146.

Hyacinthe, C., Anschutz, P., Carbonel, P., Jouanneau, J.M., Jorissen, F.J., 2001. Early diagenetic processes in the muddy sediments of the Bay of Biscay. Marine Geology 177, 111-128.

Jian, Z., Wang, L., Kienast, M., Sarthein, M., Kuhnt, W., Lin, H., et al., 1999. Benthic foraminiferal paleoceanography of the South China Sea over the last 40,000 years. Marine Geology 156, 159-186.

Jorissen, F.J., 1987. The distribution of benthic foraminifera in the Adriatic Sea. Marine Micropaleontology 12, 21-48.

Jorissen, F.J., Fontanier, C., Thomas, E., 2007. Paleoceanographical proxies based on deep-sea benthic foraminiferal assemblage characteristics. In: Hillaire-Marcel, C., de Vernal, A. (Eds.), Paleoceanography of the Late Cenozoic. Methods in Late Cenozoic paleoceanography. Developments in marine geology, 1. Elsevier, Amsterdam, pp. 263-325.

Jorissen, F.J., de Stigter, H.C., Widmark, J.G.V., 1995. A conceptual model explaining benthic foraminiferal microhabitats. Marine Micropaleontology $22,3-15$.

Jorissen, F.J., Wittling, I., Peypouquet, J.P., Rabouille, C., Relexans, J.C., 1998. Live benthic foraminiferal faunas off Cap Blanc, NW Africa: community structure and microhabitats. Deep-Sea Research I 45, 2157-2188.

Kitazato, H., Shirayama, Y., Nakatsuka, T., Fujiwara, S., Shimanaga, M., Kato, Y., et al., 2000. Seasonal phytodetritus deposition and responses of bathyal benthic foraminiferal populations in Sagami Bay, Japan: preliminary results from "Project Sagami 1996-1999". Marine Micropaleontology 40, 135-149.

Koho, K.A., García, R., de Stigter, H.C., Epping, E., Koning, E., Kouwenhoven, T.J., et al., 2008. Sedimentary labile organic carbon and pore water redox control on species distribution of benthic foraminifera: A case study from Lisbon-Setúbal Canyon (southern Portugal). Progress in Oceanography 79, 55-82.

Koho, K.A., Kouwenhoven, T.J., de Stigter, H.C., van der Zwaan, G.J., 2007. Benthic foraminifera in the Nazare Canyon, Portuguese continental marg: Sedimentary environments disturbance. Marine Micropaleontology $66,27-51$. 
Laborde, P., Urrutia, J., Valencia, V., 1999. Seasonal variability of primary production in the Cap-Ferret Canyon area (Bay of Biscay) during the ECOFER cruises. Deep-Sea Research II 46, 2057-2079.

Langezaal, A.M., Jorissen, F.J., Braun, B., Chaillou, G., Fontanier, C., Anschutz, P., et al., 2006. The influence of seasonal processes on geochemical profiles and foraminiferal assemblages on the outer shelf of the Bay of Biscay. Continental Shelf Research 26, 1730-1755.

Larkin, K.E., Gooday, A.J., 2009. Foraminiferal faunal responses to monsoondriven changes in organic matter and oxygen availability at 140 and $300 \mathrm{~m}$ water depth in the NE Arabian Sea. Deep-Sea Research II 56, 403-421.

Le Floch, J., 1968. Sur la circulation de l'eau d'origine méditerranéenne dans le Golfe de Gascogne et ses variations à courte période. Cahiers Océanographiques 20, 653-661.

Licari, L.N., Schumacher, S., Wenzhöfer, F., Zabel, M., Mackensen, A., 2003. Communities and microhabitats of living benthic foraminifera from the tropical east Atlantic: impact of different productivity regimes. Journal of Foraminiferal Research 33, 10-31.

Linke, P., Lutze, G.F., 1993. Microhabitats preferences of benthic foraminifera: a static concept or a dynamic adaptation to optimize food acquisition? Marine Micropaleontology 20, 215-234.

Loubere, P., 1991. Deep-sea benthic foraminiferal assemblage response to a surface ocean productivity gradient: a test. Paleoceanography 6, 193-204.

Loubere, P., 1994. Quantitative estimation of surface ocean productivity and bottom water oxygen concentration using benthic foraminifera. Paleoceanography 9, 723-737.

Lutze, G.F., 1979. Benthic foraminifera at Site 397: fluctuations and ranges in the Quaternary. In: von Rad, U., Ryan, W.-B.-F., et, al. (Eds.), Initial Reports of Ocean Drilling Program 47. US Government Printing Office, Washington, DC, pp. 419-431.

Lutze, G.F., 1980. Depth distribution of benthic foraminifera on the continental margin off NW Africa, "Meteor" Forschungserbegnisse. Reihe C 32, 31-80.

Lutze, G.F., 1986. Uvigerina species of the eastern north Atlantic. Utrecht Micropaleontological Bulletins 35, 21-46.

Lutze, G.F., Coulbourn, W., 1984. Recent benthic foraminifera from the continental margin off northwest Africa: community structure and distribution. Marine Micropaleontology 8, 361-401.

Mackensen, A., Douglas, R.G., 1989. Down-core distribution of live and deadwater benthic foraminifera in box cores from the Weddell Sea and the California continental borderland. Deep-Sea Research 36, 879-900.

Mackensen, A., Sejrup, H.P., Jansen, E., 1985. The distribution of living benthic foraminifera on the continental slope and rise off southwest Norway. Marine Micropaleontology 9, 275-306.

Mojtahid, M., Jorissen, F., Lansard, B., Fontanier, C., Bombled, B., Rabouille, C., 2009. Spatial distribution of live benthic foraminifera in the Rhône prodelta: Faunal response to a continental-marine organic matter gradient. Marine Micropaleontology 70, 177-200.

Moodley, L., Hess, C., 1992. Tolerance of infaunal benthic foraminifera for low and high oxygen concentrations. Biological Bulletin 183, 94-98.

Morigi, C., Jorissen, F.J., Gervais, A., Guichard, S., Borsetti, A.M., 2001. Benthic foraminiferal faunas in surface sediments off NW Africa: Relationship with organic flux to the ocean floor. Journal of Foraminiferal Research 31 , $350-368$.

Murray, J.W., 2006. Ecology and Applications of Benthic Foraminifera. Cambridge University Press, Cambridge, 426p.

Ohga, T., Kitazato, H., 1997. Seasonal changes in bathyal foraminiferal populations in response to the flux of organic matter (Sagami Bay, Japan). Terra Nova 9, 33-37.
Parker, F.L., 1958. Eastern Mediterranean Foraminifera. Reports of the Swedish deep-sea expedition 1947-1948, vol. VIII: Sediment cores from the Mediterranean and the Red Sea 2, $283 \mathrm{p}$.

Pflum, C.E., Frerichs, W.E., 1976. Gulf of Mexico deep-water Foraminifers Cushman Foundation for Foraminiferal Research Special Publication 14, $1-125$.

Phleger, F.B, 1951. Ecology of foraminifera, northwest Gulf Mexico. Geological Society of America 46, 1-88.

Pujos-Lamy, A., 1973. Répartition bathymétrique des foraminifères benthiques profonds du Golfe de Gascogne. Comparaison avec d'autres aires océaniques. Revista Española de Micropaleontologia 5, 213-234.

Rathburn, A.E., Corliss, B.H., 1994. The ecology of living (stained) deep-sea benthic foraminifera from the Sulu Sea. Paleoceanography 9, 87-150.

Rathburn, A.E., Corliss, B.H., Tappa, K.D., Lohmann, K.C., 1996. Comparison of the ecology and stable isotopic compositions of living (stained) benthic foraminifera from the Sulu and South China Seas. Deep-Sea Research 43 , 1617-1646.

Revsbeck, N.-P., 1983. In-situ measurements of oxygen profiles of sediments by use of oxygen microelectrodes. In: Ganuger, G., Forstner, H. (Eds.), Polarographic oxygen sensors. Springer, Berlin, pp. 265-273.

Revsbeck, N.P., Jørgensen, B.B., 1986. Microelectrodes: their use in microbial ecology. Advances in Microbial Ecology 9, 293-352.

Risgaard-Petersen, N., Langezaal, A.-M., Ingvardsen, S., Schmid, M.C., Jetten, M.S.M., Op den Camp, H.J.M., et al., 2006. Evidence for complete denitrification in a benthic foraminifer. Nature 443, 93-96.

Schmidt, S., Howa, H., Mouret, A., Lombard, F., Anschutz, P., Labeyrie, L., 2009. Particle fluxes and recent sediment accumulation on the Aquitanian margin of Bay of Biscay. Continental Shelf Research 29, 1044-1052.

Schmiedl, G., Mackensen, A., Miller, P.J., 1997. Recent Benthic foraminifera from the South Atlantic Ocean: Dependence on food supply and water masses. Marine Micropaleontology 32, 249-287.

Schönfeld, J., 2006. Taxonomy and distribution of the Uvigerina peregrina plexus in the tropical to Northeastern Atlantic. Journal of Foraminiferal Research 36, 355-367.

Silva, K.A., Corliss, B.C., Rathburn, A.E., Thunnell, R.C., 1996. Seasonality of living benthic foraminifera from the San Pedro Basin, California Borderland. Journal of Foraminiferal Research 26, 71-93.

Streeter, S.S., 1973. Bottom water and benthonic foraminifera in the North Atlantic - glacial-interglacial contrasts. Quaternary Research 3, 131-141.

Strickland, J.D.H., Parsons, T.R., 1972. A practical handbook of seawater analysis. Bulletin of Fisheries Resource B Canada 167, 311.

Suess, E., 1980. Particulate organic carbon flux in the ocean-surface productivity and oxygen utilization. Nature 288, 260-263.

Tréguer, P., Le Corre, P., Grall, J.R., 1979. The seasonal variations of nutrients in the upper waters of the Bay of Biscay region and their relation to phytoplanktonic growth. Deep-Sea Research 26, 1121-1152.

Van Aken, H.M., 2000a. The hydrography of the mid-latitude Northeast Atlantic Ocean: The deep water masses. Deep-Sea Research I 47, 757-788.

Van Aken, H.M., 2000b. The hydrography of the mid-latitude Northeast Atlantic Ocean: The intermediate water masses. Deep-Sea Research I 47, 789-824.

Van Aken, H.M., 2001. The hydrography of the mid-latitude northeast Atlantic Ocean: The thermocline water mass. Deep-Sea Research I 48, 237-267.

Van Leeuwen, R.J.W., 1986. The distribution of Uvigerina in the late Quaternary sediments of the deep eastern South Atlantic. Utrecht Micropaleontological Bulletins 35, 47-66.

Walton, W.R., 1952. Techniques for recognition of living Foraminifera. Contribution of the Cushman Foundation for Foraminiferal Research 3, 56-60. 